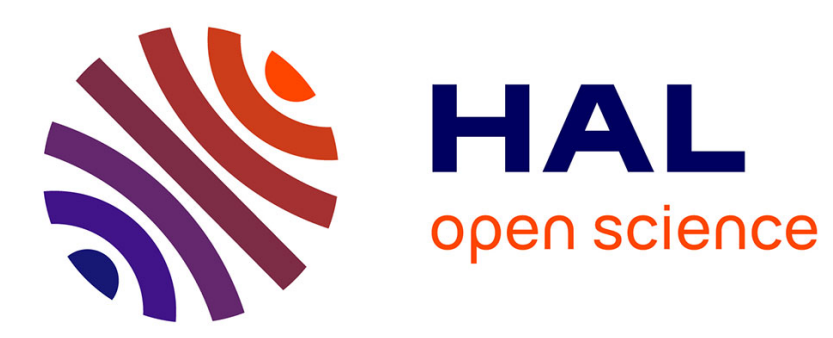

\title{
Effect of 1-pyrrolidine dithiocarbamate on the galvanic coupling resistance of intermetallics - Aluminum matrix during corrosion of AA 2024-T3 in a dilute $\mathrm{NaCl}$
} Wafaa Qafsaoui, Martin W. Kendig, Hubert Perrot, Hisasi Takenouti

\section{- To cite this version:}

Wafaa Qafsaoui, Martin W. Kendig, Hubert Perrot, Hisasi Takenouti. Effect of 1-pyrrolidine dithiocarbamate on the galvanic coupling resistance of intermetallics - Aluminum matrix during corrosion of AA 2024-T3 in a dilute NaCl. Corrosion Science, 2015, 92, pp.245-255. 10.1016/j.corsci.2014.12.011 . hal-01114871

\author{
HAL Id: hal-01114871 \\ https://hal.science/hal-01114871
}

Submitted on 12 Feb 2015

HAL is a multi-disciplinary open access archive for the deposit and dissemination of scientific research documents, whether they are published or not. The documents may come from teaching and research institutions in France or abroad, or from public or private research centers.
L'archive ouverte pluridisciplinaire HAL, est destinée au dépôt et à la diffusion de documents scientifiques de niveau recherche, publiés ou non, émanant des établissements d'enseignement et de recherche français ou étrangers, des laboratoires publics ou privés. 


\section{Accepted Manuscript}

Effect of 1-pyrrolidine dithiocarbamate on the galvanic coupling resistance of intermetallics - aluminum matrix during corrosion of AA 2024-T3 in a dilute $\mathrm{NaCl}$

W. Qafsaoui, M.W. Kendig, H. Perrot, H. Takenouti

PII: S0010-938X(14)00593-9

DOI: http://dx.doi.org/10.1016/j.corsci.2014.12.011

Reference: CS 6143

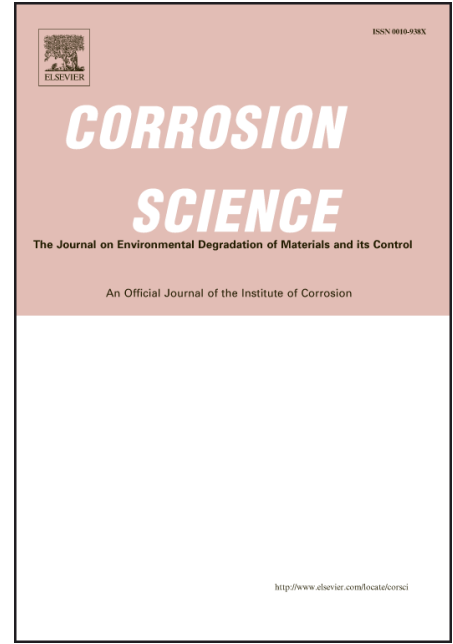

To appear in:

Corrosion Science

Received Date:

28 July 2014

Accepted Date:

10 December 2014

Please cite this article as: W. Qafsaoui, M.W. Kendig, H. Perrot, H. Takenouti, Effect of 1-pyrrolidine dithiocarbamate on the galvanic coupling resistance of intermetallics - aluminum matrix during corrosion of AA 2024-T3 in a dilute NaCl, Corrosion Science (2014), doi: http://dx.doi.org/10.1016/j.corsci.2014.12.011

This is a PDF file of an unedited manuscript that has been accepted for publication. As a service to our customers we are providing this early version of the manuscript. The manuscript will undergo copyediting, typesetting, and review of the resulting proof before it is published in its final form. Please note that during the production process errors may be discovered which could affect the content, and all legal disclaimers that apply to the journal pertain. 
Effect of 1-pyrrolidine dithiocarbamate on the galvanic coupling resistance of intermetallics - aluminum matrix during corrosion of AA 2024-T3 in a dilute $\mathrm{NaCl}$

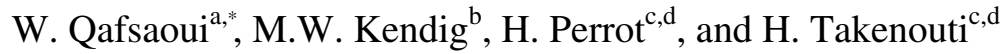 \\ a Laboratoire de l'Eau et de l'Environnement, Faculté des Sciences d'El Jadida, BP 20, \\ 24000 El Jadida, Morocco. wqafsaoui@gmail.com \\ ${ }^{\mathrm{b}}$ Kendig Research Associates LLC, 496 Hillsborough, Thousand Oaks, CA 91361. USA, \\ martin.kendig@verizon.net \\ ${ }^{\mathrm{c}}$ Sorbonne Universités, UPMC Univ Paris VI, UMR 8235, Laboratoire Interfaces et Systèmes \\ Electrochimiques (LISE), 4, place Jussieu, case courrier 133, F-75005, Paris, France, \\ hisasi.takenouti@upmc.fr \\ ${ }^{\mathrm{d}}$ CNRS, UMR 8235, LISE, F-75005, Paris, France, \\ hubert.perrot@upmc.fr
}

\begin{abstract}
1-pyrrolidine dithiocarbamate (PDTC) effect on galvanic coupling resistance of AA 2024-T3 alloy in $0.2 \mathrm{~g} \mathrm{~L}^{-1} \mathrm{NaCl}$ was evaluated by different electrochemical/gravimetric methods and surface analysis. The results obtained from polarization curves and electrochemical quartz crystal microbalance measurements showed that PDTC forms an adsorbed film on the Cu-rich particles, likely through a $\mathrm{Cu}^{\mathrm{I}}$-PDTC complex. At high concentrations, PDTC significantly decreases the alloy reactivity thereby providing a marked corrosion protection. SEM-EDX analysis showed that PDTC adsorbs preferentially on the $\mathrm{Al}-\mathrm{Cu}-\mathrm{Mg}$ particles. Electrochemical impedance spectroscopy measurements corroborate these results and show furthermore that PDTC addition increases the galvanic coupling resistance.
\end{abstract}

Key words: Aluminum, copper-rich particles, surface film, oxygen reduction reaction, EIS, EQCM.

"Corresponding author: Fax: +212.523 3421 87; E-mail: wqafsaoui@ gmail.com 


\section{Introduction}

Despite the susceptibility of $2 \mathrm{XXX}$ series of aluminum alloys to galvanic corrosion in chloride media [1,2], they continue to be the material of choice in different industries, particularly for several applications in the aerospace domain, due especially to their lightness and their advantageous mechanical properties. $2 \mathrm{XXX}$ series are obtained by addition of alloying elements, mainly copper, to confer high mechanical strength to the alloys thus formed. However, $\mathrm{Cu}$ addition produces a heterogeneous microstructure containing intermetallic inclusions, mainly $\mathrm{Al}-\mathrm{Cu}-\mathrm{Mg}$ (S-phase), $\mathrm{Al}-\mathrm{Cu}-\mathrm{Mn}-\mathrm{Fe}$, and other $\mathrm{Cu}-$ rich minor phases in the case of AA 2024-T3 alloy. In chloride media, all types of coarse intermetallic particles strongly affect the corrosion behavior of the AA 2024-T3 alloy but in different ways and extent. The common theory concerning the corrosion mechanism of this alloy [1, 3-9] states that $\mathrm{Al}-\mathrm{Cu}-\mathrm{Mg}$ particles are initially active with respect to the matrix and are partially dissolved by dealloying resulting in a copper-rich remnant, which then behaves as a cathodic site and induces peripherical matrix corrosion near the particle due to $\mathrm{pH}$ increase [10]. Concerning the $\mathrm{Al}-\mathrm{Cu}-\mathrm{Mn}-\mathrm{Fe}$ coarse intermetallics, they are always considered as cathodic sites and promote the matrix dissolution around them. This dissolution continues as long as the intermetallics retain electrical contact with the matrix, and is cathodically controlled due to the smaller area of these particles. In addition, the cathodic nature of the $\mathrm{Al}-\mathrm{Cu}-\mathrm{Mn}-\mathrm{Fe}$ particles leads to rapid reduction of oxygen with consequent increase of the $\mathrm{pH}$ in their proximity which in turn causes alkaline attack of the matrix adjacent to these particles. Besides, a secondary effect of their cathodic nature is the reduction at their location of copper ions dissolved in solution, which leads to nodular $\mathrm{Cu}$ deposits [3].

In chloride solutions and in chloride-containing sulfate solutions, the poor resistance to corrosion of AA 2024-T3 alloy was attributed to the aggressiveness of chloride and sulfate ions to copper [11-14]. This suggests that the protection of AA 2024-T3 alloy against 
localized corrosion in such environments could be mitigated by the protection of $\mathrm{Cu}$-rich particles. Hence, the use of compounds that generally inhibit the corrosion of $\mathrm{Cu}$ appears to be a promising approach for corrosion inhibition of the alloy. Several compounds have been identified as potential inhibitors for the alloy by extensive studies on the corrosion inhibition of copper [15-18].

In a previous study [19], a statistical analysis of pit nucleation times of AA 2024-T3 alloy in chloride media has shown that 1,2,3 benzotriazole (BTAH), one of the most studied inhibitors for copper [20-22], modifies the pit nucleation rate. In a wide range of applied potentials, the pit nucleation rate was decreased by a factor greater than five in the presence of BTAH. This compound prevents pitting corrosion of the alloy by interacting with $\mathrm{Cu}$-rich particles. From electrochemical noise measurements [23], we showed that BTAH inhibits both localized and generalized corrosion of AA 2024-T3 in sulfate-containing chloride solutions. An insoluble polymeric complex of $\mathrm{Cu}^{\mathrm{I}}$-BTA forms on the $\mathrm{Cu}$-rich particles, and lowers the rate of oxygen reduction reaction (ORR), which in turn prevents the dissolution of the $\mathrm{Al}$ matrix. We showed also [24] that electro-polymerization of 3-amino-1,2,3-triazole (ATA) on AA 2024-T3 alloy surface leads to the formation of a polymeric film on $\mathrm{Cu}$-rich particles. This film protects the alloy against localized corrosion by reducing the rate of the ORR.

Several studies were undertaken to reduce the reactivity of AA 2024-T3 particles. For example, Ianuzzi and Frankel [25] suggest that metavanadates inhibit corrosion of AA 2024T3 by blocking the ORR at intermetallic sites. Zhu et al. showed that the silicates block a number of cathodic sites on the AA 2024-T3 surface by forming covalent bonds of Al-O-Si at the interface [26]. Aldykewicz et al. reported that Ce inhibits the corrosion of AA 2024 through blocking the intermetallics to ORR with a Ce oxide film [27]. Ferreira et al showed that rare earth ions, such as $\mathrm{Ce}^{3+}$ and $\mathrm{La}^{3+}$, lead to the formation of hydroxide deposits on $\mathrm{S}$ phase particles buffering the local increase of $\mathrm{pH}$ and acting as a diffusion barrier depleting 
corrosion in active sites [7]. Yan et al. suggest that incorporation of oxyanions as inhibiting dopants into the polypyrrole Al flake composite coatings leads to efficient corrosion protection of the AA 2024-T3 alloy. The composite coating functions as both a reservoir for corrosion inhibitors and an oxygen scavenger [28]. Gupta et al. reported that polyanilinelignosulfonate epoxy coating on AA 2024-T3 alloy improves the corrosion resistance of the alloy in $0.6 \mathrm{M} \mathrm{NaCl}$ due to the release of dopant at the defect site by formation of aluminumsulfonate complex [29]. These studies investigating inhibitors of localized corrosion of AA 2024 , in a variety of environments, have multiplied in recent years with the goal of replacing chromates, since chromates provide excellent protection for aluminum alloys [30] but are carcinogenic and quite toxic.

For several years, our interest has focused on dithiols modified molecules, particularly the 1pyrrolidine dithiocarbamate (PDTC) which is a non-toxic product found in different applications in the areas of agriculture and medicine [31]. Previously, this compound showed to inhibit the corrosion of steel in water pipes [32]. Elsewhere, Liao et al. [33] demonstrated that PDTC forms a self-assembling membrane on $\mathrm{Cu}$ through the interaction of its two $\mathrm{S}$ atoms with the $\mathrm{Cu}$ surface then inhibits corrosion when the resulting surface immersed in 0.5 mol L ${ }^{-1} \mathrm{HCl}$. Previous experiments on AA 2024-T3 in chloride media [34] showed that PDTC considerably slows down the rate of both cathodic and anodic processes. This beneficial effect likely results from the interaction of PDTC with the $\mathrm{Cu}$-rich particles since other studies [3537] have demonstrated that the dithiols inhibit the ORR on copper in neutral chloride solutions. A more complete study of the system $\mathrm{Cu} /$ PDTC in a chloride solution [38] was realized to help understanding the effect of PDTC on localized corrosion inhibition of AA 2024-T3 alloy. The results obtained on copper showed that PDTC is a good mixed inhibitor for $\mathrm{Cu}$ in $0.5 \mathrm{~mol} \mathrm{~L} \mathrm{LaCl}^{-1} \mathrm{Nt}$ acts by stabilizing the surface products that form on copper surface i.e. $\mathrm{CuCl}$ and $\mathrm{Cu}_{2} \mathrm{O}$, which consequently reduces the surface of $\mathrm{Cu}$ exposed to the 
aggressive medium thereby lowering the reactivity of the electrode.

In the light of the results obtained from $\mathrm{Cu} / \mathrm{PDTC}$ system, this work describes the role of PDTC in the inhibition of localized corrosion of AA 2024-T3 in $0.2 \mathrm{~g} \mathrm{~L}^{-1} \mathrm{NaCl}$, the solution representing a weakly aggressive natural water.

\section{Experimental methods}

\subsection{Electrodes}

The disk electrodes were made of pure copper and pure aluminum cylinder rods (Goodfellow, $99.999 \%$ of quality) of $5 \mathrm{~mm}$ in diameter, and AA 2024-T3 aluminum alloy rod of $1.3 \mathrm{~mm}$ in diameter, the composition of which is given in table 1. Figure 1 shows a SEM micrograph of AA 2024-T3 alloy on which coarse intermetallic particles are clearly evidenced. First, the lateral part of the cylinders was covered with a cataphoretic paint (PGG W975 + G323) to avoid the electrolyte infiltration in the lateral part of the cylinder rod. The rods were then embedded into an allylic resin or a thermal shrinking sheath. For each material, the electrode surface was abraded, just before experiments by rotating emery paper up to 1200 grade under water flow, and then rinsed abundantly with deionized water.

For EQCM (Electrochemical Quartz Crystal Microbalance) experiments, two $0.2 \mathrm{~cm}^{2}$ gold electrodes were vapor deposited on both faces of the quartz crystal blade to impose an electrical field for oscillation. One of the faces was used as a working electrode, and for this purpose thin layers of test materials were vapor deposited onto the gold electrode by radio frequency plasma assisted sputtering from targets of either pure aluminum or AA 2024-T3 aluminum alloy purchased from Goodfellow. Sputtering, carried out at $2 \mathrm{~Pa}$ of argon gas, lasted 20 minutes producing sputter-deposited aluminum or aluminum alloy of about $1 \mu \mathrm{m}$ thick. Figure 2 shows the surface morphology of the alloy deposit. Its chemical composition is shown in table 2. Note that the $\mathrm{Cu}$-containing alloy appeared homogeneous without secondary 
phases observed for the AA 2024-T3 alloy. Nevertheless, this material provides a surface of a homogeneous $\mathrm{Al}$ alloy containing $\mathrm{Cu}$. Clearly, composition and microstructure of the layer vapor deposited are different from those of the solid alloy: alloying elements do not form coarse intermetallic particles but are homogenously dispersed throughout the layer. It is, indeed, quite difficult to approach the complex microstructure of the alloy [39-43]. Thus, EQCM results of the vapor deposited layer may be quite different from those that may be obtained with the target. However it is interesting to study if PDTC interacts with $\mathrm{Cu}$ uniformly dispersed in such layer.

The nominal resonant oscillation frequency of the quartz blade was $6 \mathrm{MHz}$. Measurements were carried out with a lab-made device and monitoring program.

The working electrode was set close to the centre of the electrolyzing cell, and under stationary conditions, i.e. without any electrolyte stirring.

The reference electrode was a calomel electrode in saturated $\mathrm{KCl}$ (SCE). All potentials are referred as measured without any correction of neither liquid junction potential nor ohmic drop. The counter electrode was a platinum grid of large surface area set close to the cell wall.

\subsection{Electrolytes}

The blank corrosion test solution was $0.2 \mathrm{~g} \mathrm{~L}^{-1} \mathrm{NaCl}$ to which $10^{-4}, 10^{-3}$, or $10^{-2} \mathrm{~mol} \mathrm{~L}^{-1}$ of PDTC $\left(\mathrm{C}_{5} \mathrm{H}_{9} \mathrm{NS}_{2}, \mathrm{M}=147.26 \mathrm{~g} \mathrm{~mol}^{-1}\right.$, supplied by Sigma $\left.{ }^{\circledR}\right)$ was added as inhibitor. $100 \mathrm{~mL}$ of electrolyte was used for each experiment. The corrosion test was carried out without purging of dissolved oxygen and maintained at $20^{\circ} \mathrm{C}$.

\subsection{Surface analysis}

The surface morphology of the electrodes was investigated with a LEICA STEREOSCAN 440 scanning electron microscope (SEM) and element analyses were performed with an energy dispersive X-ray analyzer (EDX; Princeton Gamma-Tech ${ }^{\mathrm{Q}}$. 


\subsection{Electrochemical measurements}

Polarization measurements were carried out in a conventional three-electrode cell. The working disk electrode was stationary and faced towards the cell bottom. Electrochemical measurements were performed after 1 hour immersion in the test solution with or without the inhibitor.

The voltammetric and impedance measurements were carried out using a Gamry potentiostat / galvanostat Model FAS-1 or 300C. Polarization curves were plotted from two independent measurements in a new test solution for each run: one from the open circuit potential towards more cathodic potentials, and another from the open circuit potential to nobler potential values at the potential scan rate of $1 \mathrm{mV} \mathrm{s}^{-1}$. Three replica experiments were carried out for each experimental condition.

The impedance measurements were performed with $10 \mathrm{mV}_{\mathrm{rms}}$ from $100 \mathrm{kHz}$ to $10 \mathrm{mHz}$ by 10 points per decade during 48 hours. For parameter regression calculation procedure, sometimes high frequency data (for instance above $40 \mathrm{kHz}$ ) were deleted since some instrumental and systematic error was observed, especially when the impedance spectrum exhibited a high capacitance (typically greater than $10 \mu \mathrm{F}$ ) at high frequency domain. The data were fitted by Simad software, a lab-made software using simplex regression calculation. For this reason, an error margin of each parameter could not be evaluated.

\section{Results and discussion}

Characterization of AA 2024-T3 / PDTC system was first realized by plotting polarization curves to assess the potential role of PDTC on the anodic and cathodic reactions occurring on the $\mathrm{Al}$ matrix with and without the $\mathrm{Cu}$-rich particles. SEM observations and analysis were then performed to view and evaluate the possible interactions between PDTC, the particles and / or the Al matrix. In the second part of the study, electrochemical quartz crystal 
microbalance measurements (EQCM) were carried out over large periods of time to estimate the PDTC effect on the surface products. Finally, the electrochemical impedance spectroscopy (EIS) was used to provide an equivalent electrical circuit model allowing understanding and characterizing the AA 2024-T3 interface.

\subsection{Voltammetry and SEM observations}

The presence of a significant quantity of $\mathrm{Cu}(\sim 4 \%)$, as alloying element in AA 2024-T3 alloy, plays a considerable role in the localized corrosion process of this alloy in chloride media [1117]. Therefore, it is important to assess and compare the electrochemical behavior of AA 2024-T3 alloy to those of pure $\mathrm{Cu}$ and pure $\mathrm{Al}$ in $0.2 \mathrm{~g} \mathrm{~L}^{-1} \mathrm{NaCl}$.

\subsubsection{Electrochemical behaviors of pure Al, pure Cu and $A A 2024-T 3$ alloy in $0.2 \mathrm{~g} \mathrm{~L}^{-1} \mathrm{NaCl}$}

Figure 3 shows the polarization curves of the three materials in $0.2 \mathrm{~g} \mathrm{~L}^{-1} \mathrm{NaCl}$. It is clear that the alloy presents an intermediate behavior between that of $\mathrm{Cu}$ and that of $\mathrm{Al}$. The anodic branch is similar to that of $\mathrm{Cu}$ in the sense that no apparent passivity occurs. The cathodic behavior is similar to that of Al with a region corresponding to a diffusion-limited ORR, and for higher potentials a domain of current increase due to hydrogen evolution.

Upon anodic polarization, the anodic dissolution predominates, as electrochemical reaction, for both the $\mathrm{Cu}$ and the AA 2024-T3 alloy. In the case of the alloy, the ORR sets the potential of the material to above its pitting potential so that no region of passivity appears in the data. For pure $\mathrm{Cu}$, there also appears no region of passivity in the $\mathrm{NaCl}$ solution as often reported in the literature $[12,44-46]$. This differs from the pure Al, which shows a small pseudo anodic plateau corresponding to a region of slight passivity. It can be clearly seen in this potential region that the pure $\mathrm{Al}$ exhibits a lower rate of anodic dissolution than the AA 2024-T3 alloy. The anodic dissolution of pure $\mathrm{Al}$ starts well below the potentials where $\mathrm{Cu}$ anodically dissolves. 
As mentioned previously, the potential scan in the cathodic direction for both AA 2024-T3 and pure $\mathrm{Al}$ exhibits two changes in slope in the polarization curve. The lower slope (nearly a plateau) may correspond to the diffusion limited ORR reaction [3-6]. However, in this region, the slope is not zero as would be expected in an entirely diffusion limited reaction. Note that under cathodic polarization, the oxygen at the electrode vicinity will be depleted, the $\mathrm{pH}$ increases and the oxides dissolve in the alkaline environment leading to increasing ORR kinetics with higher cathodic polarization. For the case of the AA 2024-T3, the curve in this region is flatter and more like a true plateau because the $\mathrm{pH}$ change would be limited. However, the plateau current density is significantly smaller than that expected for the diffusion of $\mathrm{O}_{2}$ in aqueous medium for stationary electrode, as this is the case for the $\mathrm{Cu}$ electrode. As stated further, for AA 2024, the ORR takes place on Cu-rich particles, i.e. at small surface area, at the open circuit potential (OCP), but at a higher cathodic polarization, ORR may take place also above the $\mathrm{Al}$ oxide. Therefore, the diffusion process may take place through the oxide layer, and not in the solution. This aspect may likely be examined more accurately by using a rotating electrode with the modulation of rotation speed (ElectroHydroDynamic impedance (EHD)).

Extrapolating the current densities for this region back to OCP for both the pure $\mathrm{Al}$ and the AA 2024-T3 shows that the cathodic current at OCP is significantly higher for the AA 2024T3 as compared to the pure Al. This result is to be associated with the presence of cathodic Cu-rich intermetallic phases in the AA 2024-T3 alloy.

In the case of the pure $\mathrm{Cu}$, the cathodic process entails reduction of $\mathrm{Cu}_{2} \mathrm{O}$ and $\mathrm{CuCl}$ formed on the surface of the $\mathrm{Cu}$ at $\mathrm{OCP}$, as well as the oxygen reduction. The $\mathrm{Cu}^{\mathrm{I}}$ products do not form on the Cu-rich particles of the AA 2024-T3 alloy during the immersion since the $\mathrm{Cu}$ is galvanically protected by the AA 2024-T3 at its OCP. Nonetheless, after long immersion periods, localized corrosion of the alloy occurs as shown in Figure 4a representing the surface 
morphology after exposure of the alloy for 24 hours to $0.2 \mathrm{~g} \mathrm{~L}^{-1} \mathrm{NaCl}$. This medium is quite aggressive to the alloy exhibiting highly localized corrosion as evidenced by the sparse and highly localized deposition of corrosion products. This has been confirmed by removing the corrosion products with an adhesive paper to show that the matrix remains intact while particles are attacked (Figure 4b). Corrosion is thus localized around the particles. This observation is well known and has been widely discussed [11, 47, 48].

\subsubsection{Effect of PDTC on AA 2024-T3 alloy behavior in $0.2 \mathrm{~g} \mathrm{~L}^{-1} \mathrm{NaCl}$}

The polarization results after the addition of PDTC to the chloride solution are presented in Figure 5. To ensure reproducibility, tests were performed at least three times. Figure 5a shows three replica of curves plotted on the alloy in $0.2 \mathrm{~g} \mathrm{~L}^{-1} \mathrm{NaCl}+10 \mathrm{mM}$ PDTC.

Results obtained at different concentration of PDTC are given in figure 5b. The addition of $0.1 \mathrm{mM}$ PDTC has little influence on the anodic reaction rate of the AA 2024-T3, but lowers the cathodic current density in the region of diffusion limited ORR. Increasing the concentration of PDTC to 1 and $10 \mathrm{mM}$ significantly decreases the ORR near the OCP so as to displace the OCP significantly to more cathodic potentials (respectively -0.56 and -0.77 V/SCE for $1 \mathrm{mM}$ and $10 \mathrm{mM}$ instead of $-0.48 \mathrm{~V} / \mathrm{SCE}$ for the blank) as well as dramatically lowering the corrosion current density from around $3 \mu \mathrm{A} \mathrm{cm}^{-2}$ for the blank to well below 0.1 $\mu \mathrm{A} \mathrm{cm}^{-2}$. A pseudo-current plateau in the anodic branch appears around $-0.48 \mathrm{~V} / \mathrm{SCE}$ in the presence of $10 \mathrm{mM}$ PDTC. One can readily remark that this behavior is similar to that obtained for pure Al (figure 3). These results suggest that PDTC, at high concentration, protects $\mathrm{Cu}$-rich particles making thus the behavior of AA 2024 alloy closer to that of pure Al.

\subsubsection{Evaluation of PDTC effect on Al matrix and Cu-rich particles}

To understand the action of PDTC on the matrix and the particles, polarization curves were 
collected for both pure $\mathrm{Al}$ and pure $\mathrm{Cu}$ in $0.2 \mathrm{~g} / \mathrm{L} \mathrm{NaCl}$ with and without $10 \mathrm{mM}$ PDTC (Figure 6).

For pure $\mathrm{Al}$, the addition of $10 \mathrm{mM}$ of PDTC has practically no effect on the kinetics of the anodic and cathodic reactions. In fact, the curves obtained with and without PDTC are virtually superimposable (Figure 6a). SEM-EDX analysis performed for the specimen exposed to $\mathrm{NaCl}$ solution with or without PDTC showed the surfaces to be practically identical. EDX analyses showed the presence of $\mathrm{Al}$ and a small level of oxygen due to a slight oxidation of the surface. This contrasts entirely with the results previously discussed for the interaction of PDTC with the AA 2024-T3 (Figure 5b). Moreover, in previous works [19, 23, 24], a similar behavior was observed with BTAH and ATA in three distinct studies. First, during the formation of anodic films in the presence of BTAH in chloride containing sulfate solutions [19], this compound was found to hinder the passive film formation on Al matrix, making it less protective against pitting corrosion. By electrochemical noise measurements at OCP [23], BTAH showed a temporary protection because no stable bond can be formed between BTAH and Al. BTAH only blocks the active sites by steric hindrance. Cyclic voltammograms measured during the electropolymerization of ATA on a pure Al surface [24] in methanol or sulfate solutions, showed continuous increase of the current densities at each cycle. Electrode surfaces were severely attacked at the end of the tests. The electrode reaction was limited to Al dissolution and formation of ATA oligomers since the current density in presence of ATA was much higher than in its absence. Clearly, organic molecules, or at least those that we have studied i.e. BTAH, ATA, and PDTC have no inhibitive effect on Al matrix but may impede the native oxide film formation on the electrode.

For pure $\mathrm{Cu}$, the addition of PDTC significantly influences both the anodic and cathodic processes (Figure 6b). The value of OCP becomes cathodic by more than 0.4 volt with this inhibitor. The anodic current density in the region between 0 and 1 volt are 3 to 4 orders of 
magnitude lower in the presence of the PDTC indicating a very strong anodic inhibition. An anodic current maximum between -0.5 and 0 volt suggests an electrosorption process that generates a $\mathrm{Cu}^{\mathrm{I}}$-PDTC surface compound.

In the cathodic region near OCP, the current density decreases by more than two orders of magnitude. This result shows that during immersion at open circuit, in the solution containing PDTC, stable and adherent products form at the $\mathrm{Cu}$ surface in good agreement with the results obtained in $0.5 \mathrm{~mol} \mathrm{~L}^{-1} \mathrm{NaCl}[38]$.

Figure 7 clearly shows the presence of a surface film resulting from immersion in $0.2 \mathrm{~g} \mathrm{~L}^{-1}$ $\mathrm{NaCl}+10 \mathrm{mM}$ PDTC solution. Furthermore, EDX analysis (table 3) confirms the interaction between PDTC and $\mathrm{Cu}$ by the presence of $\mathrm{S}$ atoms in the surface film. This element in the surface layer is evaluated to be about $18 \%$ in an atomic percentage. By analogy with the results obtained with the system $\mathrm{Cu} / \mathrm{PDTC}$ in $0.5 \mathrm{M} \mathrm{NaCl}$ [38], one may suggest that even at low content of $\mathrm{NaCl}$, PDTC strongly interacts with the $\mathrm{Cu}$ surface to stabilize the $\mathrm{Cu}^{\mathrm{I}}$ products, mainly $\mathrm{Cu}_{2} \mathrm{O}$ and $\mathrm{CuCl}$. In the $0.5 \mathrm{M} \mathrm{NaCl}$ environment, it was found that the surface layer of $\mathrm{Cu}^{\mathrm{I}}$ products is stabilized sufficiently to strongly hinder the ORR.

Clearly, the PDTC has a strong interaction with metallic $\mathrm{Cu}$. This result provides important evidence that PDTC inhibits corrosion of AA 2024-T3 through its interaction with the Cu-rich intermetallic particles, and not on the aluminum matrix.

3.1.4. EDX cartography of AA 2024-T3 alloy after immersion in $0.2 \mathrm{~g} \mathrm{~L}^{-1} \mathrm{NaCl}+\mathrm{PDTC}$

Figure 8 presents the surface cartography of AA 2024-T3 alloy after 1 hour immersion in 0.2 $\mathrm{g} \mathrm{L}^{-1} \mathrm{NaCl}$ containing $10 \mathrm{mM}$ PDTC. In order to study the interaction between PDTC and the main precipitates i.e. $\mathrm{Al}-\mathrm{Cu}-\mathrm{Mg}$ and $\mathrm{Al}-\mathrm{Cu}-\mathrm{Mn}-\mathrm{Fe}$ particles, the distributions of $\mathrm{Mg}, \mathrm{Fe}$ and $\mathrm{S}$ were analyzed. This figure shows two important results:

1- The whole surface is protected since no localized corrosion is revealed around the particles. 
Note that without PDTC and in the same conditions the particles were readily removed by pulling with adhesive tape (figure 4).

2- $\mathrm{S}$ atoms of the PDTC molecule are only found at the $\mathrm{Al}-\mathrm{Cu}-\mathrm{Mg}$ particles (figure 8 ) and this is confirmed by the EDX analysis of one particle of $\mathrm{Al}-\mathrm{Cu}-\mathrm{Mg}$ (Table 4). This particle analysis revealed some $10.4 \%$ of S atoms. Note that the same observation and analysis were obtained after 24 hours immersion.

This result shows that PDTC protects the AA 2024-T3 alloy even though it selectively reacts with a fraction of the particles. Al-Cu-Mg particles correspond to the $\mathrm{S}$ phase $\left(\mathrm{Al}_{2} \mathrm{CuMg}\right)$ often described in the literature $[11,47,49]$. This phase is round shaped, varies between 5 and $30 \mu \mathrm{m}$ and represents about $60 \%$ of all of the intermetallic particles present in the AA 2024 alloy $[36,49,50]$. It occupies $1.2 \%$ of the total surface of the material. This phase dispersed over the alloy surface is initially anodic with respect to the matrix, but ennobles as a result of the selective and rapid dissolution of $\mathrm{Mg}$ from the precipitate and becomes cathodic with respect to the zone adjacent to the precipitate. In contrast, $\mathrm{Al}-\mathrm{Cu}-\mathrm{Mn}-\mathrm{Fe}$ particles have an irregular form and a size varying between $5 \mu \mathrm{m}$ and $40 \mu \mathrm{m}$ [49]. Moreover, the reactivity of these particles do not change during immersion, as it is the case for $\mathrm{Al}-\mathrm{Cu}-\mathrm{Mg}$, but stay cathodic with respect to the matrix in the whole immersion period. It can then be assumed that PDTC interacts with $\mathrm{Al}-\mathrm{Cu}-\mathrm{Mg}$ particles during their initial anodic phase to form stable $\mathrm{Cu}^{\mathrm{I}}-$ PDTC complexes. On the other hand, as seen in figure 8, all types of particles are protected since no dissolution of the matrix appears around the particles. It could be then assumed that PDTC may inhibit the ORR taking place on Al-Cu-Mn-Fe particles without forming a deposit of a sufficient extent to be verified by EDX.

\subsection{Gravimetric measurements}

Gravimetric measurements were carried out, in $0.2 \mathrm{~g} \mathrm{~L}^{-1} \mathrm{NaCl}$ at $\mathrm{OCP}$ with pure $\mathrm{Al}$ or AA 2024-T3 alloy sputtered on gold-coated quartz crystals. For the alloy sputter deposited from 
the AA 2024-T3 alloy target, the deposit contains $\mathrm{Cu}, \mathrm{Fe}, \mathrm{Mg}$, and $\mathrm{Mn}$ but of somewhat differing ratios to that of the target alloy (table 2). It is also obvious that the microstructure, specifically the presence of the intermetallics of the bulk alloy, cannot be achieved by the sputtering technique. Figure 2 presenting a cross section of the deposit shows, as expected, a homogenous microstructure. On the other hand, the deposit is sufficiently thick $(\sim 1 \mu \mathrm{m})$ to simulate the electrochemical behavior of a solid electrode. Nonetheless, we are aware that the response of such a deposit can be relevant as to the behavior of the individual alloying elements in the AA 2024-T3 alloy rather than the response of intermetallic phases.

\subsubsection{Pure Al and alloy deposited from the AA 2024-T3 target in the blank solution}

Figure 9 shows for both pure $\mathrm{Al}$ (fig. 9a) and the $\mathrm{Cu}$ containing alloy (fig. 9b), a mass change during the first hours of immersion in $0.2 \mathrm{~g} \mathrm{~L}^{-1} \mathrm{NaCl}$, due to the oxide formation and dissolution of the materials. In fact, a competition exists between these two processes particularly at the early immersion period. After this stage, that lasts about $4 \mathrm{~h}$ for pure $\mathrm{Al}$ and 6h for the alloy, surface products deposition prevails over the metal dissolution leading to a continuous mass gain.

For pure $\mathrm{Al}$, the gravimetric behavior is mainly composed of three parts. The first part lasts until about 4 hours of immersion when the dissolution produces a metal loss of about $6 \mu \mathrm{g}$ $\mathrm{cm}^{-2}$ with a $\Delta \mathrm{m} / \Delta$ slope of around $-0.5 \mathrm{ng} \mathrm{cm}^{-2} \mathrm{~s}^{-1}$. Between 4 and 6.5 hours of immersion, most of the surface products are adherent oxides explaining the rise in recorded mass at a rate of $1.8 \mathrm{ng} \mathrm{cm}^{-2} \mathrm{~s}^{-1}$. Beyond 6 hours of immersion, the kinetics of the surface products growth becomes faster.

For the alloy sputter deposited from the AA 2024-T3, a significant increase in mass up to 2.6 $\mu \mathrm{g} \mathrm{cm}^{-2}$ can be observed during the first period of immersion ( $17 \mathrm{~min}$.). This could be due to a rapid oxidation of the surface. Note that this surface is composed of $\mathrm{Al}$ and alloying 
elements uniformly dispersed. Between $17 \mathrm{~min}$ and $1.5 \mathrm{~h}$ of immersion, a region of dissolution and redeposition can be observed and could be related to the initiation of localized corrosion, notably unstable pitting. Beyond this nucleation step, the propagation of localized corrosion becomes the limiting rate exhibiting a significant mass decrease, i.e. approximately $4.2 \mu \mathrm{g} \mathrm{cm}^{-2}$ after 7 hours of immersion. Afterwards, corrosion products are deposited on the surface and the quartz resonant frequency indicates a significant mass increase. It should be noted that the experiments in the blank solution were stopped after several hours of immersion test for both electrodes, because of a significant mass increase.

\subsubsection{Pure Al in $0.2 \mathrm{~g} \mathrm{~L}^{-1} \mathrm{NaCl}+10 \mathrm{mM}$ PDTC}

When PDTC is added to the corrosion test solution, Figure 9a seems to show no mass increase for pure Al. Thus, this test was prolonged for up to $60 \mathrm{~h}$. The insert shows the variation of mass on an enlarged scale during this long-term test, and then, mass fluctuations around zero, between -0.8 and $0.8 \mu \mathrm{g} \mathrm{cm}^{2}$, were observed. This shows that corrosion products, likely aluminum oxides, form during the mass increase stage but these oxides appear to be precarious since a mass decrease follows. PDTC seems to disable the oxide film growth on pure Al. This result is consistent with that obtained with the polarization curves namely the fact that PDTC has no significant influence on the electrochemical behavior of pure Al. On the other hand, the fluctuations in mass confirm previous studies $[19,23,24]$ showing that PDTC, or other organic inhibitors, disrupts the formation of oxides on the Al surface in chloride media.

\subsubsection{Alloy sputter deposited from AA 2024-T3 target in $0.2 \mathrm{~g} \mathrm{~L}^{-1} \mathrm{NaCl}+10 \mathrm{mM} P D T C$}

For the alloy sputter deposited from AA 2024-T3 target, addition of $10 \mathrm{mM}$ PDTC induces a small increase in mass, followed by almost no change as shown in figure 9b. Actually, a magnified scale of the mass axis during $60 \mathrm{~h}$ (insert of fig.9b) shows a weak but quite rapid gain in mass during the first hours of immersion, followed by a slower and continuous 
increase. Beyond $45 \mathrm{~h}$ of immersion, the slope $\Delta \mathrm{m} / \Delta$ approaches zero. A similar behavior was observed for $\mathrm{Cu}$ [38] and the rise in mass was attributed to the formation of $\mathrm{CuCl}$ layer stabilized by PDTC leading to an interface more resistant to corrosion damages.

From the EQCM measurements, it can be concluded that PDTC considerably reduces the reactivity of the alloying elements added to harden the alloy, especially $\mathrm{Cu}$, to chloride ions. PDTC contributes hence to significantly decrease the reactivity of the electrode. This result may be extended to the solid alloy.

\subsection{Electrochemical impedance spectroscopy}

EIS measurements were carried out for pure $\mathrm{Al}$ and AA 2024-T3 alloy, in $0.2 \mathrm{~g} \mathrm{~L}^{-1} \mathrm{NaCl}$ at OCP with or without PDTC, during at least a $48 \mathrm{~h}$ period. The impedance data were collected every two hours.

\subsubsection{Effect of PDTC on pure Al EIS diagrams}

Nyquist plots for pure $\mathrm{Al}$ sample, immersed in $0.2 \mathrm{~g} \mathrm{~L}^{-1}$ with or without $10 \mathrm{mM}$ PDTC at different immersion times, are presented in Figure 10. With or without PDTC, the diameter of the capacitive loop increases with immersion time. Regarding PDTC effect, this compound seems to have a beneficial effect on the resistance of pure Al during the first hours of immersion. Howeyer, after $15 \mathrm{~h}$ this trend is reversed especially in the low frequency domain. This result confirms once again that PDTC disturbs the pure Al interface, and reduces its corrosion resistance. The protection by PDTC occurs only in an early immersion period because no stable bond forms between PDTC and the surface oxides of Al. The augmentation of the impedance spectra by PDTC shows however no comparison to that observed, as described in section 3.3.2, to the case of AA 2024-T3. As shown in a previous study with BTAH [23], PDTC might impede the arrival of chloride ions at the pure $\mathrm{Al}$ interface by steric hindrance, temporary blocking the active sites. 
Though not clearly seen, two time constants are necessary to suitably simulate the impedance data. Note that the simulations proposed in this report do not represent unique models for the impedance response, but rather provide models for the impedance consistent with known properties of the materials. Therefore, an equivalent circuit composed of two ladder parallel R-C circuits was used (Fig. 11). The high frequency circuit $\mathrm{R}_{\mathrm{f}}-\mathrm{C}_{\mathrm{f}}$ corresponds to the capacitance and resistance of the surface film, and the low frequency loop represented by $\mathrm{R}_{\mathrm{t}^{-}}$ $C_{d}$ represents double layer capacitance and charge transfer resistance. The coefficients $n_{f}$ and $\mathrm{n}_{\mathrm{d}}$ allowed a depressed feature of the impedance spectra as revealed in Nyquist diagram to be reproduced.

Impedance parameters obtained by simplex regression calculation, using a lab-made software (Simad), are shown in figure 12. In the blank solution, the film resistance $\left(\mathrm{R}_{\mathrm{f}}\right)$ decreases initially from 112.5 to $42.5 \Omega \mathrm{cm}^{2}$ at the $7^{\text {th }} \mathrm{h}$. This resistance reaches approximately $60 \Omega \mathrm{m}^{2}$ after $63 \mathrm{~h}$ of immersion. A similar feature is also noticed for the film capacitance $\left(\mathrm{C}_{\mathrm{f}}\right)$ change. It attains $5 \mu \mathrm{F} \mathrm{cm}^{-2}$ at the end of the test. Such behavior could be explained by assuming that the native oxide film is destroyed during the first hours of immersion due to the aggressive action of chloride ions but replaced by a new thinner and resistive oxide layer. This corroborates the results obtained by EQCM. When PDTC is present in the aggressive medium, $R_{f}$ and $C_{f}$ values are lower indicating a slightly thicker and less resistive film, which is in agreement with the voltammetry and the EQCM results.

The charge transfer resistance $\left(\mathrm{R}_{\mathrm{t}}\right)$ increases progressively with immersion time in the blank solution to reach $6.3 \mathrm{M} \Omega \mathrm{cm}^{2}$ at the end of the test $(63 \mathrm{~h})$. This high value of $\mathrm{R}_{\mathrm{t}}$ reflects the presence of a passive film on the pure $\mathrm{Al}$ surface. As for the double layer capacitance $\left(\mathrm{C}_{\mathrm{d}}\right)$, its value decreases during the first hours $(7 \mathrm{~h})$ then increases continuously up to approximately $100 \mu \mathrm{F} \mathrm{cm}^{-2}$ after $63 \mathrm{~h}$. With PDTC, EIS parameters are almost constants during the whole immersion test. $\mathrm{R}_{\mathrm{t}}$ is lower $\left(\sim 450 \mathrm{k} \Omega \mathrm{cm}^{2}\right)$ since no passive film forms on pure Al surface and 
$\mathrm{C}_{\mathrm{d}}$ is about $26 \mu \mathrm{F} \mathrm{cm} \mathrm{cm}^{-2}$. These results show that PDTC has a harmful effect on corrosion resistance of pure Al. These effects may be extended to the Al matrix of the AA 2024-T3 alloy.

\subsubsection{Effect of PDTC on AA 2024-T3 alloy EIS diagrams}

Figure 13a presents the impedance spectrum in a Nyquist diagram, for the AA 2024-T3 alloy sample at the corrosion potential after $15 \mathrm{~h}$ immersion in $0.2 \mathrm{~g} \mathrm{~L}^{-1} \mathrm{NaCl}$, without and with PDTC at different concentrations. Note that the size of the EIS diagram increases with PDTC concentration likely due to its beneficial effect on both anodic and cathodic processes. Analysis of impedance spectra of the AA 2024-T3 alloy are generally tricky because of the complex nature of its microstructure and the processes taking place such as oxide formation, matrix dissolution, ORR on the intermetallics and galvanic coupling between the matrix and the particles. Hence, it is not easy to have accurate details directly from the spectra. However, it can be noticed that for the inhibitor concentrations lower than $0.1 \mathrm{mM}$, a diffusion impedance can be observed. For the blank solution, this impedance corresponds to the bounded diffusion whereas at $0.1 \mathrm{mM}$, the diffusion is the Warburg type in the frequency domain used. The presence of PDTC therefore markedly hinders the diffusion process. For higher PDTC concentrations, the diffusion impedance is no longer observed, instead a depressed capacitive loop replace it. This is clearly evidenced in Bode plots (figure 13b) with phase markedly greater than $45^{\circ}$. The reaction rate is sufficiently reduced such that the diffusion process no longer intervenes in the electrode kinetics.

To better understand these results, the electrochemical behavior of the AA 2024-T3 alloy / PDTC interface have to be considered. The model must take into account the fact that the alloy microstructure is heterogeneous and that PTDC acts selectively to intermetallic particles. Several configurations of equivalent circuit models were used in the literature to fit the experimental data obtained for inhibited AA 2024-T3 alloy [51, 52]. However, these 
models gave no details on the active sites since they take into account only the parameters of the inhibitor layer, the oxide film and the charge transfer. Other authors [26] have included the water penetration in the organic film and the pit formation. In this study, we considered the works of Mansfeld et al. [53-55] concerning the modeling for the impedance behavior of aluminum alloys under localized corrosion. According to Mansfeld et al. the impedance data for $\mathrm{Al}$ alloys in $\mathrm{NaCl}$ solutions show characteristic changes, in the low frequency region when pits have exceeded a certain minimum depth. They developed a model taking into account the passive surface and the fraction of actively pitting area. In this work, Mansfeld's model was improved by introducing a coupling resistance, $\mathrm{R}_{\mathrm{ac}}$, between anodic process mainly on the matrix and cathodic sites associated with the intermetallic phases. The electrical equivalent circuit illustrated in Figure 14 was used. This circuit has two parallel branches representing the anodic and cathodic processes at the interface, coupled by an anodic-cathodic coupling resistance, $\mathrm{R}_{\mathrm{ac}}$.

The physical nature of the circuit elements is attributed as follows.

a- $\mathbf{R}_{\mathbf{s}}$ : solution resistance.

b- $\mathbf{R}_{\mathbf{a c}}$ : resistance representing the coupling between anodic and cathodic sites.

c- $\mathbf{n}_{\mathbf{f}}, \mathbf{n}_{\mathbf{a}}, \mathbf{n}_{\mathbf{c}}$ : Cole-Cole coefficients representing the depressed feature of the capacitive loops in the Nyquist plan [56, 57].

d- Cathodic area A: It is the overall area of the cathodic sites. " $A$ " represents the three different areas; intermetallic particles, $\mathrm{Cu}$ enriched area due to the dealloying of the particles, and redeposited $\mathrm{Cu}$ in the vicinity of the particles [3-10]. In this model, although the particles are different and have different sizes, a mean particles radius " $\mathrm{r}$ " is used. The contribution of cathodic ORR is represented by $\left(\mathrm{R}_{\mathrm{c}}, \mathrm{Q}_{\mathrm{c}}\right)$,

Oxygen diffusion and ORR take place at the cathodic sites. The size of these sites are small compared with the diffusion thickness of uniformly accessible surface, thus the concentration 
gradient depicts a spherical shape. This is the reason that we used equation (1) representing the hemispherical diffusion of oxygen:

$$
Z_{\mathrm{d}}=\frac{\mathrm{R} \cdot T \cdot r}{z^{2} \cdot \mathrm{F}^{2} \cdot C_{0} \cdot D}\left(\frac{1}{1+\sqrt{\mathrm{j} \cdot \omega \cdot \tau_{\mathrm{d}}}}\right)
$$

where R, $T$ and $\mathrm{F}$ denote the gas constant $\left(8.314 \mathrm{~J} \mathrm{~mol}^{-1} \mathrm{~K}^{-1}\right)$, the absolute temperature $(\mathrm{K})$ and the Faraday (96485 $\mathrm{C} \mathrm{mol}^{-1}$ ), respectively. $z, r, C_{0}$ and $D$ stand for the number of electron exchanged in the reaction, the radius of the active cathodic area, the concentration of the dissolved oxygen in the solution bulk and the diffusion coefficient of $\mathrm{O}_{2}$ respectively. $\omega$ stands for the angular frequency $\left(\mathrm{rad} \mathrm{s}^{-1}\right)$ determined by the frequency of the AC signal $\mathrm{f}(\mathrm{Hz})$ :

$$
\omega 2 \cdot \pi \cdot f(f \text { in } \mathrm{Hz})
$$

And the diffusion time constant is determined by:

$$
\tau_{\mathrm{d}}=\frac{r^{2}}{D}
$$

Now, let us consider that the cathodic process takes place at sites having a total fractional surface area, A. The effects of PDTC concentration and immersion time, on the cathodic branch parameters $\left(A, r, R_{c}, Q_{c}, n_{c}\right)$, were then evaluated by a simplex regression calculation with the experimental data.

e- Anodic area (1-A): This part of the circuit represents the aluminum matrix. It takes into account the dielectric character of the oxide film with the ionic leakage through the surface film $\left(R_{f}, Q_{f}\right)$ and the anodic process occurring on the $\mathrm{Al}$ matrix $\left(\mathrm{R}_{\mathrm{a}}, \mathrm{Q}_{\mathrm{a}}\right)$. The impedance of the anodic process concerns only the area (1-A) and the parameters evaluated by the simplex calculation in this branch of the circuit are, as can be seen readily on Figure $14, Q_{a}, R_{a}, n_{a}, Q_{f}$, $\mathrm{R}_{\mathrm{f}}$, and $\mathrm{n}_{\mathrm{f}}$.

The coupling resistance $\mathrm{R}_{\mathrm{ac}}$ that connect the cathodic and anodic branches, and the solution resistance $R_{\mathrm{s}}$ are also evaluated by the simplex regression calculations. 
There are 13 parameters to be fitted, because $Z_{d}$ for one cathodic area contains only one unknown parameter $r$. The latter is fixed by Equation (3) by fitting calculation. A is then determined by experimental $Z_{d}$ determined by parallel connection of cathodic area. $R_{s}$ is the high frequency limit of the experimental impedance. Finally, parameters composing anodic and cathodic areas and the coupling resistance may interfere one with another making the fitting procedure less reliable.

Experimental diagrams were suitably fitted with this equivalent circuit. As this work is focused on the galvanic corrosion, and consequently the ORR on the particles, only $R_{\mathrm{ac}}$ and the physical parameters of the cathodic sites will be discussed here because of the uncertainty described above.

Figure 15 presents the variation of the coupling resistance $\mathrm{R}_{\mathrm{ac}}$ as a function of time for different PDTC concentrations. Note that without or with low content of PDTC, $R_{\mathrm{ac}}$ lies in the range around $200 \mathrm{ohm} \mathrm{cm}^{2}$ just after the immersion. Then, it decreases during several hours. After that $R_{\mathrm{ac}}$ increases continuously to reach the steady value of $400 \Omega \mathrm{m}^{2}$ after about $24 \mathrm{~h}$ of immersion in the solution containing $0.1 \mathrm{mM}$ PDTC. This figure shows that at low concentrations, PDTC can only increase the coupling resistance after one day of immersion. On the other hand, for higher concentrations, the coupling resistances are initially $300 \Omega \mathrm{cm}^{2}$ and $1 \mathrm{k} \Omega \mathrm{cm}^{2}$ for the $1 \mathrm{mM}$ and $10 \mathrm{mM}$ PDTC, respectively, but evolve towards the steady state value $\left(400 \Omega \mathrm{cm}^{2}\right)$ after 30 hours of immersion. Note that after this immersion time, and whatever the inhibitor concentration, the galvanic coupling resistance $\mathrm{R}_{\mathrm{ac}}$ becomes only twice as high as that observed for the blank solution. This result shows that addition of PDTC to the aggressive medium slightly increases the resistance for the galvanic corrosion coupling between the matrix and the $\mathrm{Cu}$-rich cathodic sites associated with the intermetallic particles. The increase of $\mathrm{R}_{\mathrm{ac}}$ indicates that the coupling between anodic and cathodic sites becomes 
more and more difficult, thus may be related to the corrosion rate. However, Figure 6 shows the OCP of pure aluminum and that of pure copper approach each other, on AA 2024-T3 the difference between these two OCP decreases, consequently, it is difficult to evaluate the corrosion rate only by $\mathrm{R}_{\mathrm{ac}}$.

Regarding the cathodic area A, figure 16 shows that without PDTC, this area varies between 2 $10^{-2}$ and $610^{-3} \mathrm{~cm}^{2}$ for the overall unit surface area, but reaches steady state around $210^{-2} \mathrm{~cm}^{2}$ after 33 hours. This area, though slightly smaller, agrees well to the surface area of the intermetallic phase of AA 2024-T3. In the presence of $0.1 \mathrm{mM}$ PDTC, the cathodic area is about 10 times smaller and stabilizes around $210^{-3} \mathrm{~cm}^{2}$ after 33 hours. For the high concentrations, the cathodic area falls dramatically to about $510^{-4} \mathrm{~cm}^{2}$ and $810^{-4} \mathrm{~cm}^{2}$, respectively in the presence of $1 \mathrm{mM}$ and $10 \mathrm{mM}$ PDTC. This result confirms the EDX observations and analysis whereby PDTC blocks an important fraction of the cathodic sites.

Further study on the cathodic site was to evaluate the variation of its radius as a function of immersion time and PDTC concentration. The characteristic diffusion radius $r$ of the active cathode was fitted, as mentioned above, from the equation of the hemispherical diffusion impedance. This parameter essentially depends on the diffusion time constant $\tau_{d}$ as defined in equation (3). As can be seen in Figure 17, for the blank solution, the radius value is on the order of $0.01 \mathrm{~cm}$ during the whole immersion time. When PDTC is added to the solution, and whatever its concentration, $r$ lies around $210^{-3} \mathrm{~cm}$ up to 12 hours. Afterwards, $r$ rises to $410^{-3}$ $\mathrm{cm}$ when the sample is immersed in the solution containing $0.1 \mathrm{mM}$ PDTC. In contrast, for high concentrations, the characteristic dimension decreases to $3.510^{-5} \mathrm{~cm}$ and $5.410^{-5} \mathrm{~cm}$ respectively for $1 \mathrm{mM}$ and $10 \mathrm{mM}$ PDTC. At high concentrations, PDTC acts efficiently on reducing the characteristic radius of the active cathodic.

Figures 16 shows that the total cathodic surface area becomes essentially constant above 12 hours of immersion, whereas for 1 and $10 \mathrm{mM}$ PDTC, $\mathrm{r}$ decreases. That means that the 
particles becomes smaller but more numerous. As a whole, $R_{a c}$ remains almost independent of immersion time beyond one day immersion in the presence of PDTC.

\section{Conclusions}

Taken together, the experiments from this study show that organic di-thiol molecules, such as PDTC, effectively inhibit the galvanic corrosion due to the coupling of the aluminum matrix with copper-rich sites associated with the intermetallic particles of the AA 2024-T3 aluminum alloy in a chloride medium. PDTC has only a small influence on the corrosion of pure aluminum which has no copper-rich particles, but strongly inhibits the anodic and cathodic reactions on pure $\mathrm{Cu}$ as evidenced by the polarization results.

Analysis of the electrochemical impedance for AA 2024-T3 / 0.2 g/L NaCl + PDTC interface shows a large increase in the galvanic coupling resistance. The effect of the inhibitor can be explained by its strong interaction with the $\mathrm{Cu}$-rich cathodic sites associated with the intermetallics through its sulfur atoms. A stable and adherent complex forms by interaction between PDTC and these particles, during their initial anodically active phase, resulting in a reduction of active cathodic surface sites. Electrochemical polarization experiments suggest strongly the formation of a stable complex, and EDX mapping of the exposed surface corroborates it by the presence of sulfur at sites corresponding to the $\mathrm{Cu}$-rich intermetallics. $\mathrm{A}$ marked inhibition for the ORR at the intermetallic sites can be seen in both the polarization results for the pure $\mathrm{Cu}$ and the AA 2024-T3 alloy.

\section{Acknowledgements}

This paper is dedicated to the memory of Dr. Philippe Rousseau who developed the program "Simad" used to fit the experimental impedance results. 


\section{References}

[1] P. Schmutz, G.S. Frankel, Corrosion Study of AA2024-T3 by Scanning Kelvin Probe Force Microscopy and In Situ Atomic Force Microscopy Scratching, J. Electrochem. Soc. 145 (1998) 2295-2306.

[2] W. Zhang, G.S. Frankel, Transitions between pitting and intergranular corrosion in AA2024, Electrochim. Acta, 48 (2003) 1193-1210.

[3] G. S. Chen, M. Gao, R. P. Wei, Microconstituent-induced pitting corrosion in aluminum alloy 2024-T3, Corrosion, 52 (1) (1996) 8-15.

[4] C.-M. Liao, J. M. Olive, M. Gao, R.P. Wei, In-situ monitoring of pitting corrosion in aluminum alloy 2024, Corrosion, 54 (6) (1998) 451-458.

[5] N. Birbilis, R. G. Buchheit, Electrochemical characteristics of intermetallic phases in aluminium alloys, Journal of. Electrochemical. Society 152 (2005) B140-B151.

[6] Y. Yoon, R. G. Buchheit, Dissolution behavior of $\mathrm{Al}_{2} \mathrm{CuMg}$ (S Phase) in chloride and chromate conversion coating solutions, Journal of. Electrochemical. Society 153 (2006) B151- B155.

[7] K.A. Yasakau, M.L. Zheludkevich, S.V. Lamaka, M.G.S. Ferreira, Mechanism of Corrosion Inhibition of AA2024 by Rare-Earth Compounds, Journal of Physical Chemistry B, 110 (2006) 5515-5528.

[8] A. Boag, A.E. Hughes, A.M. Glenn, T.H. Muster, D. McCulloch, Corrosion of AA2024-T3 Part I: Localised corrosion of isolated IM particles, Corrosion Science 53 (2011) $17-26$.

[9] R.G. Buchheit, M.A. Martinez, L.P. Montes, Evidence for $\mathrm{Cu}$ Ion Formation by Dissolution and Dealloying the $\mathrm{Al}_{2} \mathrm{CuMg}$ Intermetallic Compound in Rotating Ring-Disk Collection Experiments, Journal of The Electrochemical Society, 147 (2000) 119-124. 
[10] L. Lacroix, L. Ressier, C. Blanc, G. Mankowski, Combination of AFM, SKPFM, and SIMS to Study the Corrosion Behavior of S-phase particles in AA2024-T351, Journal of The Electrochemical Society, 155 (2008) C131-C137.

[11] C. Blanc, B. Lavelle, G. Mankowski, The role of precipitates enriched with copper on the susceptibility to pitting corrosion of the 2024 aluminium alloy, Corrosion Science 39 (1997) 495-510.

[12] W. Qafsaoui, G. Mankowski, F. Dabosi, The pitting corrosion of pure and low alloyed copper in chloride-containing borate buffered solutions, Corrosion Science 34 (1993) 17-25.

[13] J. P. Duthil, G. Mankowski, A. Giusti, The synergetic effect of chloride and sulphate on pitting corrosion of copper, Corrosion Science 38 (1996) 1839-1849.

[14] G. Mankowski, J. P. Duthil, A. Giusti, The pit morphology on copper in chloride-and sulphate- containing solutions, Corrosion Science 39 (1997) 27-42.

[15] Y. I. Kuznetzov, Organic Inhibitors of Corrosion of Metals, Plenum Press, New York, NY, 1996.

[16] F. Ammelot, C. Fiaud, E. M. M. Sutter, Application of photoelectrochemical methods for the characterization of $\mathrm{Cu}(\mathrm{I})$ oxide layers modified in the presence of corrosion inhibitors, Electrochim. Acta 42 (1997) 3565-3574.

[17] M. Fleischmann, I.R. Hill, G. Mengoli, M.M. Musiani, J. Akhavan, A comparative study of the efficiency of some organic inhibitors for the corrosion of copper in aqueous chloride media using electrochemical, surface enhanced Raman scattering techniques, Electrochim. Acta 30 (1985) 879-888.

[18] H. Otmacic Curkovic, E. Stupnisek-Lisac, H Takenouti, Electrochemical quartz crystal microbalance and electrochemical impedance spectroscopy study of copper corrosion inhibition by imidazoles, Corrosion Science 51 (2009) 2342-2348. 
[19] C. Blanc, W. Qafsaoui, G. MacCarthy, G. Mankowski, Inhibition of the pitting corrosion of 2024 aluminum alloy by 1,2,3-benzotriazole, Abstract 560, Joint meeting of the ECS and ISE, Vol. 2001- 2, San Francisco, CA, Sept 2-7, 2001.

[20] I. Dugdale, J. B. Cotton, An electrochemical investigation on the preventing of staining of copper by benzotriazole, Corrosion Science 3 (1963) 69-74.

[21] J. B. Cotton and I. R. Scholes, Benzotriazole and related compounds as corrosion inhibitors for copper, British Corrosion Journal 2 (1) (1967) 1-5.

[22] G. W. Poling, Reflection infra-red studies of films formed by benzotriazole on $\mathrm{Cu}$, Corrosion Science 10 (1970) 359-370.

[23] W. Qafsaoui, H. Huet, H. Takenouti, Analysis of the inhibitive effect of BTAH on localized corrosion of Al 2024 from electrochemical noise measurements, Journal of the Electrochemical Society 156 (2), (2009) C67-C74.

[24] W. Qafsaoui, H. Takenouti, Corrosion protection of 2024-T3 aluminium alloy by electro-polymerized 3-amino 1,2,3-triazole in sulphate solution containing chloride, Corrosion Science 52 (2010) 3667-3676.

[25] M. Iannuzzi, G.S. Frankel, Mechanisms of corrosion inhibition of AA 2027-T3 by vanadates, Corrosion Science 49 (2007) 2371-2391.

[26] D. Zhu, W.J. Van Ooij, Corrosion protection of AA 2024-T3 by bis-[3(triethoxysilyl)propyl]tetrasulfide in sodium chloride solution. Part 2: mechanism for corrosion protection, Corrosion Science 45 (2003) 2177-2197.

[27] A.J. Aldykewicz, Jr., H.S. Isaacs, A.J. Davenport, The investigation of cerium as a cathodic inhibitor for aluminium-copper Alloys, Journal of the Electrochemical Society 142 (10) (1995) 3342-3350. 
[28] M. Yan, C.A. Vetter, V.J. Gelling, Corrosion inhibition performance of polypyrrole Al flake composite coatings for Al alloys, Corrosion Science 70 (2013) 37-45.

[29] G. Gupta, N. Birbilis, A.B. Cook, A.S. Khanna, Polyaniline-lignosulfonate/epoxy coating for corrosion protection of AA2024-T3, Corrosion Science 67 (2013) 256-267.

[30] Military Specification MIL-C-81706, Chemical Conversion Materials for Coating Aluminum and Aluminum Alloys, June 1970.

[31] J. Chen, C. Du, J. Kang, J. Wang, $\mathrm{Cu}^{2+}$ is required for pyrrolidine dithiocarbamate to inhibit histone acetylation and induce human leukemia cell apoptosis, Chemico-Biological Interactions, 171 (1) (2008) 26-36.

[32] A.E. Al-Rawajfeh, E. M. Al-Shamaileh, Inhibition of corrosion in steel water pipes by ammonium pyrrolidine dithiocarbamate (APDTC), Desalination 206 (2007) 169-178.

[33] Q.-Q. Liao, Z.-W. Yue, D. Yang, Z.-H. Wang, Z.-H. Li, H.-H. Ge, Y.-J. Li, Self assembled monolayer of ammonium pyrrolidine dithiocarbamate on copper detected using electrochemical methods, surface enhanced Raman scattering and quantum chemistry calculations, Thin Solid Films 519 (2011) 6492 - 6498.

[34] M. Kendig, W. Qafsaoui , H. Takenouti, F. Huet, Organic corrosion inhibitors for highstrength aluminum, Nace Research in Progress Symposium, session : Coatings and Inhibitors, Corrosion/08, New Orleans- Louisiana (USA), Mars 2008.

[35] M. Kendig, M. Hon, J. Sinko, Inhibition of oxygen reduction on copper in neutral sodium chloride, corrosion inhibition - non ferrous metals, ECS Transactions 1 (9) (2006) 119-129.

[36] M. Kendig, M. Hon, A hydrotalcite-like pigment containing an organic anion corrosion inhibitor corrosion, passivation, and anodic films, Electrochemical and Solid State Letters 8 (2005) B10-B11. 
[37] M. Kendig, C. Yan, Critical concentrations for selected oxygen reduction reaction inhibitors corrosion, passivation, and anodic films, Journal of the Electrochemical Society 151 (2004) B679-B682.

[38] W. Qafsaoui, M.W. Kendig, H. Perrot, H. Takenouti, Coupling of electrochemical techniques to study copper corrosion inhibtion in $0.5 \mathrm{~mol} \mathrm{~L}-1 \mathrm{NaCl}$ by 1-pyrrolidine dithiocarbamate, Electrochimica Acta 87 (2013) 348-360.

[39] Y. Liu, M.A. Arenas P. Skeldon, G.E. Thompson, P. Bailey, T.C.Q. Noakes, H. Habazaki, K. Shimizu, Anodic behaviour of a model second phase:Al-20at.\%Mg-20at.\%Cu, Corrosion Science 48 (2006) 1225-1248.

[40] C.Blanc, A. Freulon, M.C. Lafont,Y. Kihn, G. Mankowski, Modelling the corrosion behaviour of $\mathrm{Al}_{2} \mathrm{CuMg}$ coarse particles in copper-rich aluminium alloys, Corrosion Science 48 (2006) 3838-3851.

[41] C.Blanc, N. Pébère, B. Tribollet, V. Vivier, Galvanic coupling between copper and aluminium in a thin-layer cell, Corrosion Science 52 (2010) 991-995.

[42] J.A. DeRose, T. Suter, A. Bałkowiec, J. Michalski, K.J. Kurzydlowski, P. Schmutz, Localised corrosion initiation and microstructural characterisation of an Al 2024 alloy with a higher $\mathrm{Cu}$ to $\mathrm{Mg}$ ratio, Corrosion Science 55 (2012) 313-325.

[43] L. Lacroix, C. Blanc, N. Pébère, G.E. Thompson, B. Tribollet, V. Vivier, Simulating the galvanic coupling between $\mathrm{S}-\mathrm{Al}_{2} \mathrm{CuMg}$ phase particles and the matrix of 2024 aerospace aluminium alloy, Corrosion Science 64 (2012) 213-221.

[44] G. Kear, B.D. Barker, F.C. Walsh, Electrochemical corrosion of unalloyed copper in chloride media-a critical review, Corrosion Science 46 (2004) 109-135.

[45] V.F. Lucey, Developments leading to the present understanding of the mechanism of pitting corrosion of copper, British Corrosion Journal 7 (1) (1972) 36-41. 
[46] E. Mattsson, Localised corrosion, British Corrosion Journal 13 (1) (1978) 5-12.

[47] R.G. Buchheit, R.P. Grant, P.F. Hlava, B. Mckenzie, G.L. Zender, Local dissolution phenomena associated with $\mathrm{S}$ phase $\left(\mathrm{Al}_{2} \mathrm{CuMg}\right)$ particles in aluminium alloy 2024-T3, Journal of the Electrochemical Society 144 (8) (1997) 2621-2628.

[48] Z. Szklarska-Smialowska, Pitting corrosion of aluminium, Corrosion Science 41 (1999) 1743-1767.

[49] M.A. Jakab, D.A. Little, J.R. Scully, Experimental and modelling studies of the oxygen reduction reaction on AA2024-T3, Journal of the Electrochemical Society 152 (8) (2005) B311- B320.

[50] A. Boag, R.J. Taylor, T.H. Muster, N. Goodman, D. McCulloch, C. Ryan, B. Rout, D. Jamieson, A.E. Hughes, Stable pit formation on AA2024-T3 in a $\mathrm{NaCl}$ environment, Corrosion Science 52 (2010) 90-103.

[51] G. Boisier, N. Portail, N. Pébère, Corrosion inhibition of 2024 aluminium alloy by sodium decanoate, Electrochimica Acta, 55 (2010) 6182-6189.

[52] M.L. Zheludkevich, K.A. Yasakau, S.K. Poznyak, M.G.S. Ferreira, Triazole and thiazole derivatives as corrosion inhibitors for AA2024 aluminium alloy, Corrosion Science 47 (2005) 3368-3383.

[53] F. Mansfeld, H. Shih, Detection of pitting with electrochemical impedance spectroscopy, Journal of the Electrochemical Society 135 (1988) 1171-1172.

[54] F. Mansfeld, S. Lin, S. Kim, H. Shih, Pitting and surface modification of SIC/Al, Corrosion Science 27 (1987) 997-1000.

[55] F. Mansfeld, M.W. Kendig, Evaluation of anodized aluminum surfaces with electrochemical impedance spectroscopy, Journal of the Electrochemical Society 135 (1988) 
828-833.

[56] E. Barsoukov, J.R. Macdonald, Impedance Spectroscopy, Theory, Experiment, and Applications, John Wiley and Sons, New York, NY, 2005, p.16.

[57] K.S. Cole, R.H. Cole, Dispersion and absorption in dielectrics- I Alternating current characteristics, Journal of Chemical Physics 9 (1941) 341-351. 
Figures

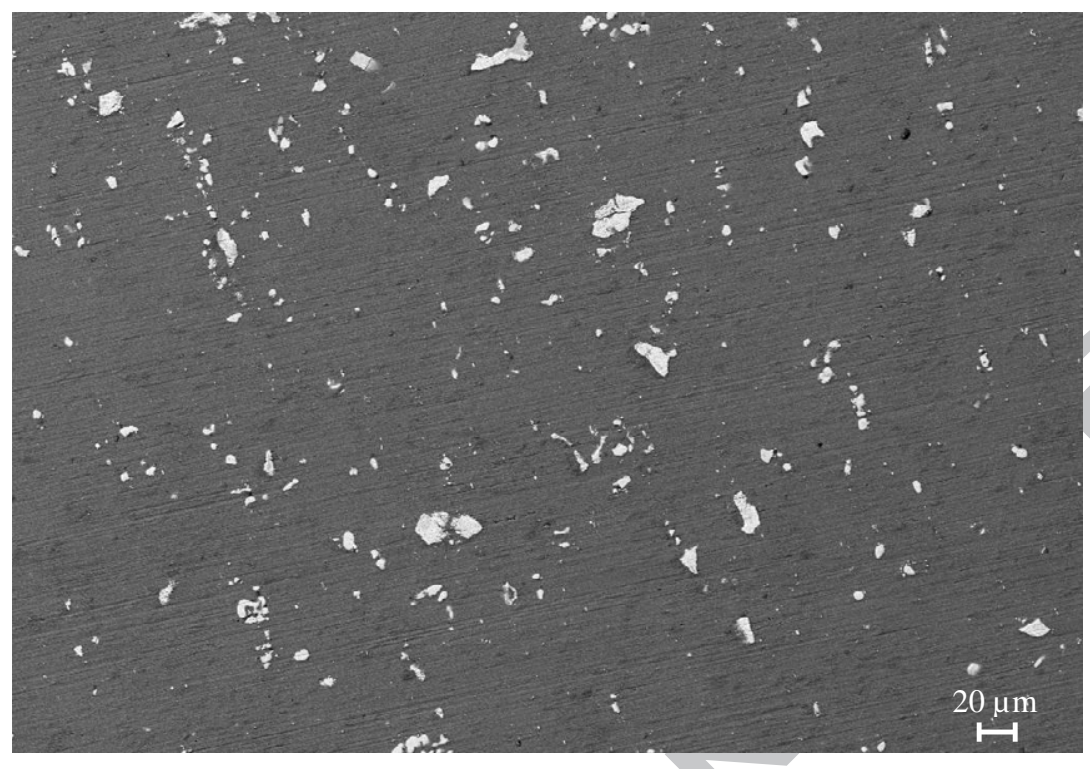

Figure 1: SEM micrograph of AA 2024-T3 alloy. 


\section{ACCEPTED MANUSCRIPT}

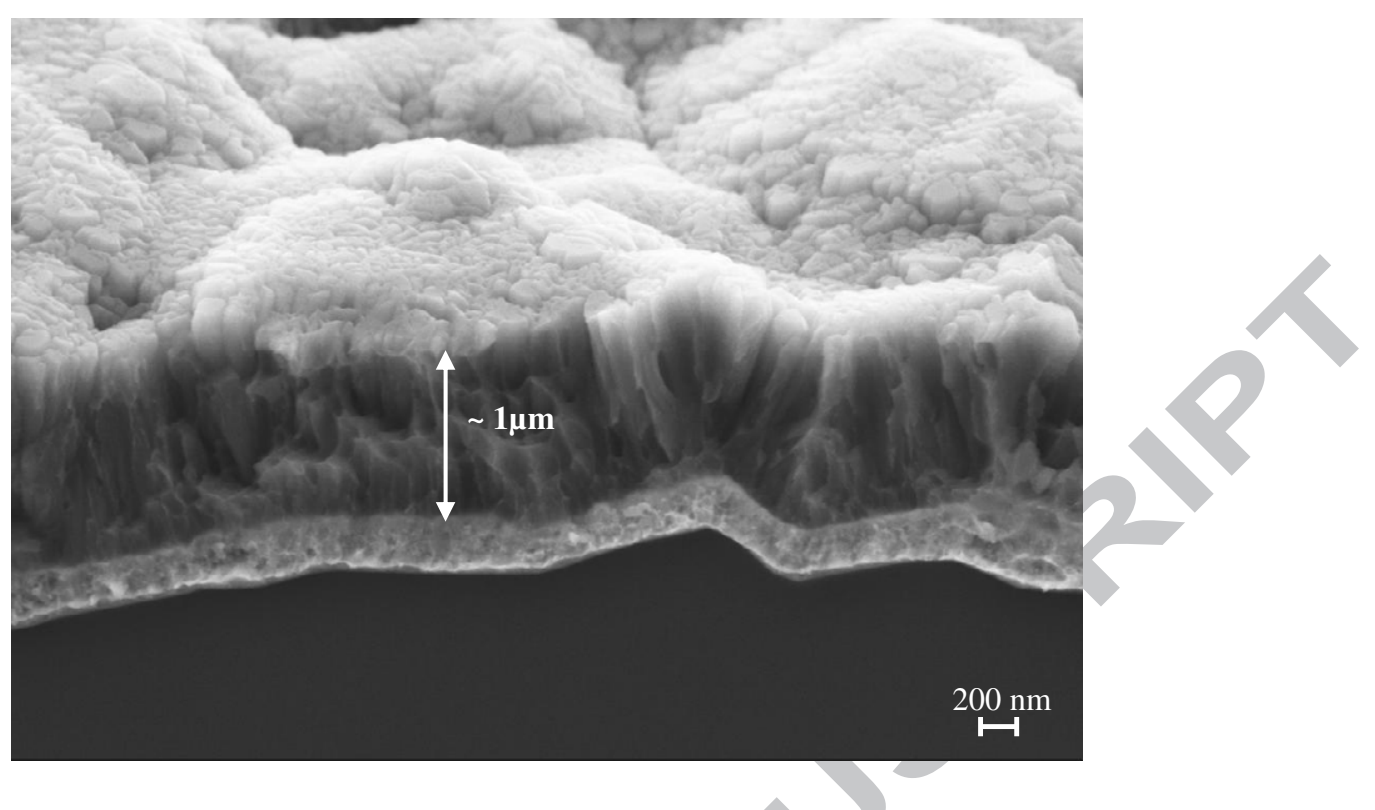

Figure 2: SEM micrograph of layer morphology deposited onto quartz electrode from

AA 2024-T3 alloy target. 


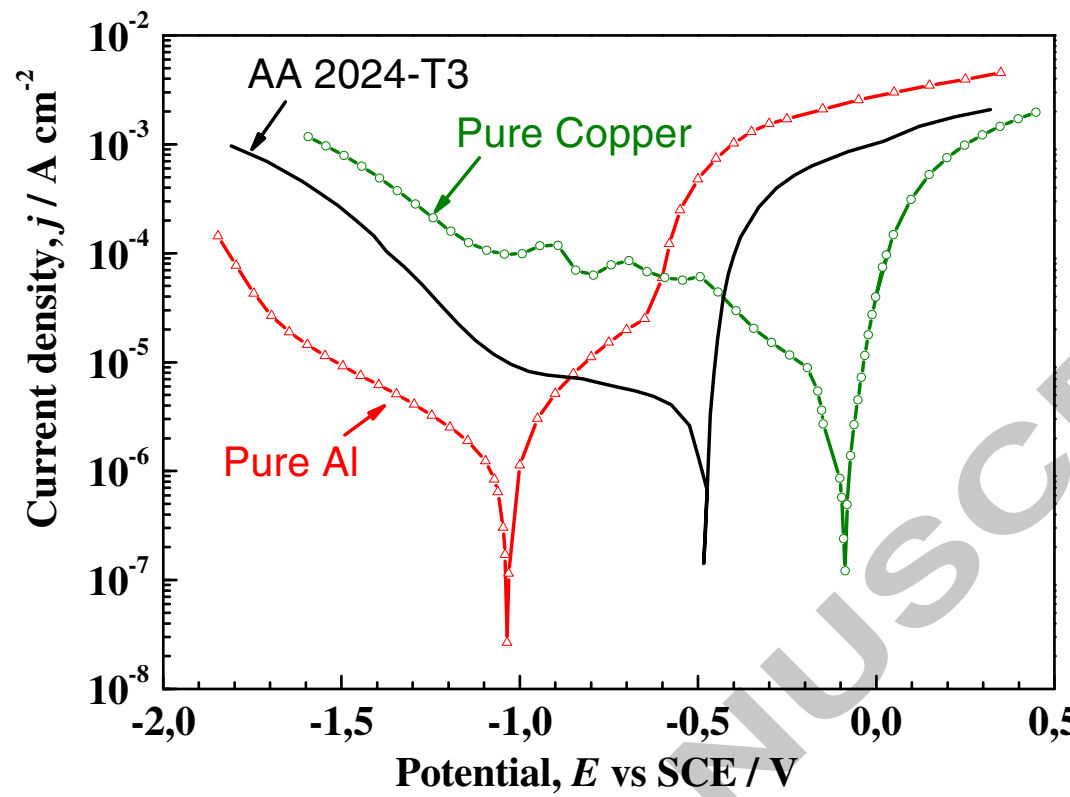

Figure 3: Polarization curves of pure Al, pure Cu and AA 2024-T3 electrodes in $0.2 \mathrm{~g} \mathrm{~L}^{-1} \mathrm{NaCl}$ solution; stationary electrodes at $20^{\circ} \mathrm{C}$. 

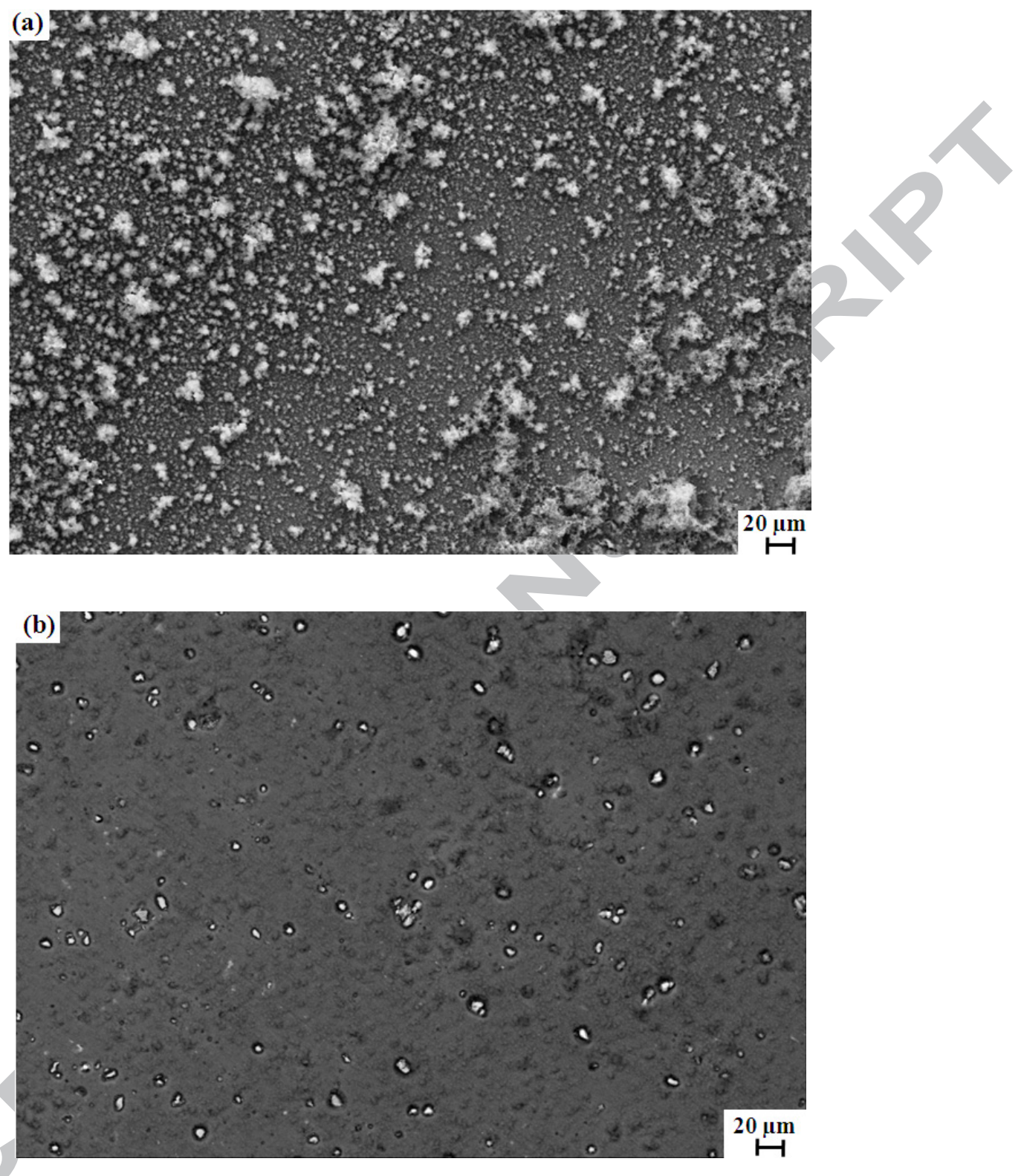

Figure 4: SEM micrographs of AA 2024-T3 electrode after 24 hours immersion in $0.2 \mathrm{~g} \mathrm{~L}^{-1} \mathrm{NaCl}$ solution with (a) and without corrosion products (b). 

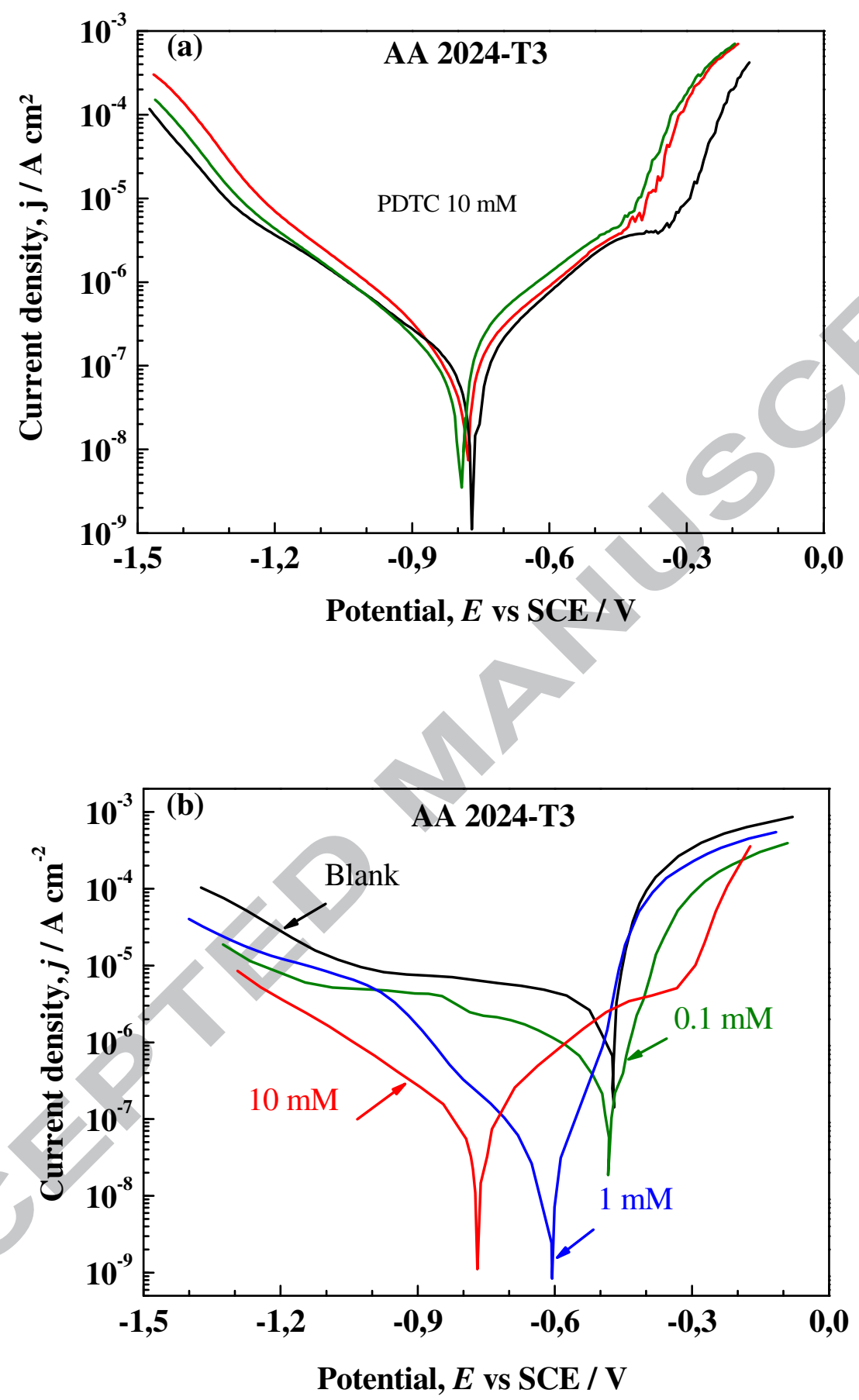

Figure 5: Reproducibility of polarization curves of AA 2024-T3 electrode in $0.2 \mathrm{~g} \mathrm{~L}^{-1} \mathrm{NaCl}+10 \mathrm{mM}$ PDTC (a) Effect of PDTC at different concentrations on the electrode kinetics of AA 2024-T3 electrode in $0.2 \mathrm{~g} \mathrm{~L}^{-1} \mathrm{NaCl}$ (b) ; stationary electrode at $20^{\circ} \mathrm{C}$. 

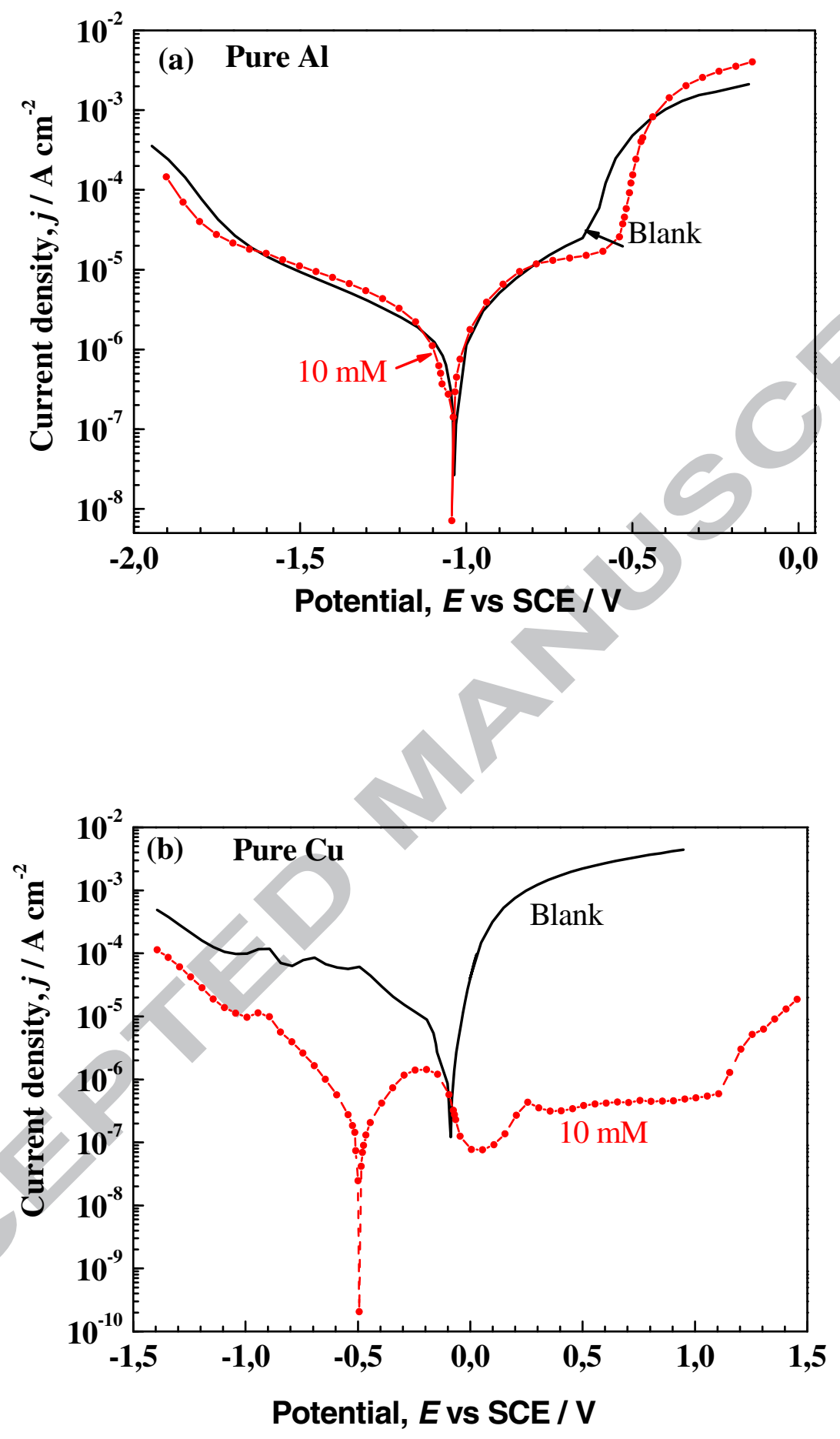

Figure 6: Effect of $10 \mathrm{mM}$ PDTC on the electrode kinetics of pure aluminum (a) and pure copper (b) in $0.2 \mathrm{~g}$ $\mathrm{L}^{-1} \mathrm{NaCl}$; stationary electrodes at $20^{\circ} \mathrm{C}$. 


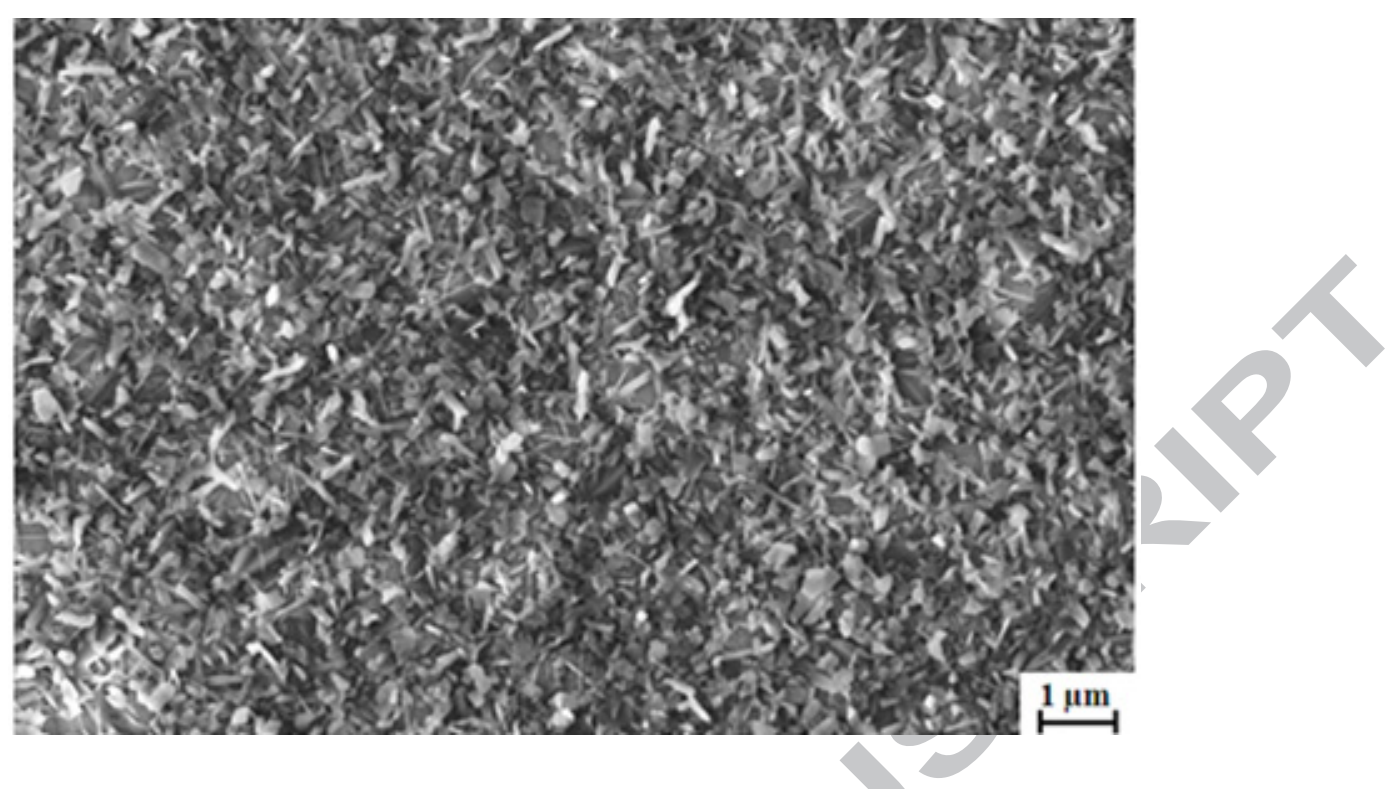

Figure 7: SEM image of copper surface after 1 hour immersion in $0.2 \mathrm{~g} \mathrm{~L}^{-1} \mathrm{NaCl}+$

$10 \mathrm{mM}$ PDTC at $20^{\circ} \mathrm{C}$. 


\section{ACCEPTED MANUSCRIPT}

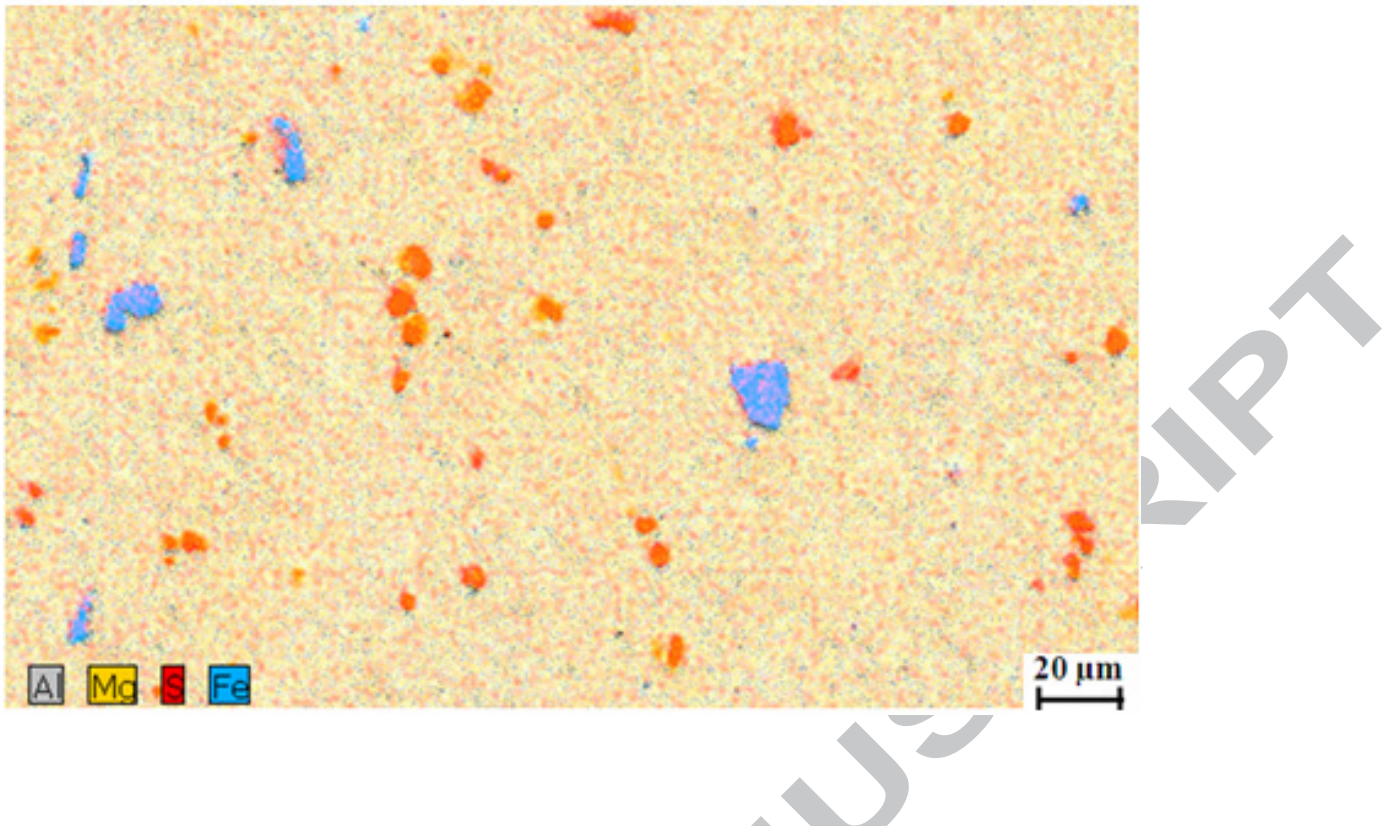

Figure 8: EDX cartography of $\mathrm{Al}, \mathrm{Mg}, \mathrm{S}$, and Fe on AA 2024-T3 electrode after 1 hour immersion in $0.2 \mathrm{~g} \mathrm{~L}^{-1}$ $\mathrm{NaCl}+10 \mathrm{mM}$ PDTC solution at $20^{\circ} \mathrm{C}$. 

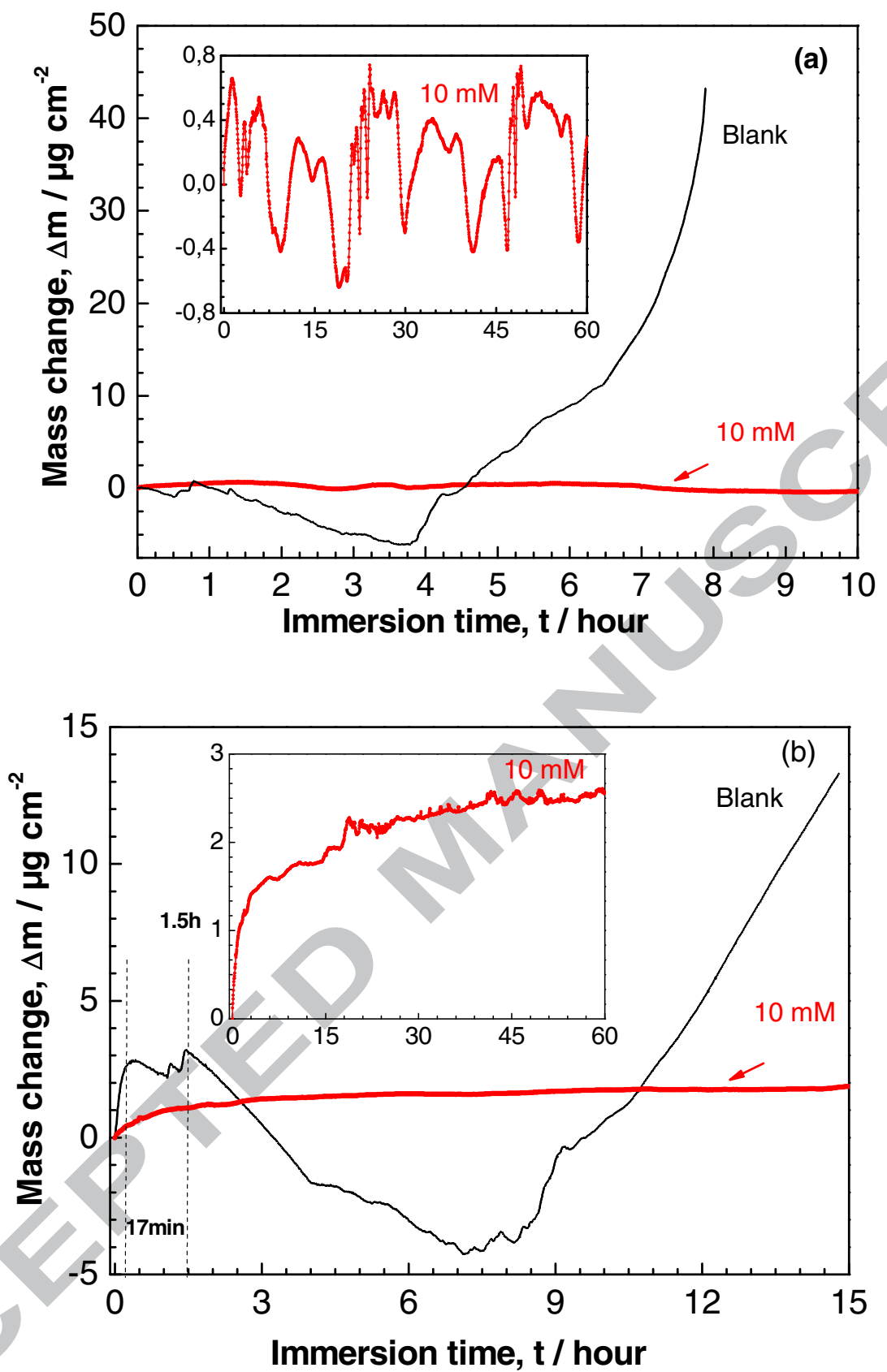

Figure 9: Gravimetric measurements on vapour deposited pure $\mathrm{Al}$ (a) and $\mathrm{AA} 2024-\mathrm{T} 3$ alloy (b) in $0.2 \mathrm{~g} \mathrm{~L}^{-1}$ $\mathrm{NaCl}$ with and without $10 \mathrm{mM}$ PDTC at $\mathrm{OCP}$ and at $20^{\circ} \mathrm{C}$.

The inserts indicate mass changes, in enlarged mass scale, in the presence of PDTC over a longer immersion time. 


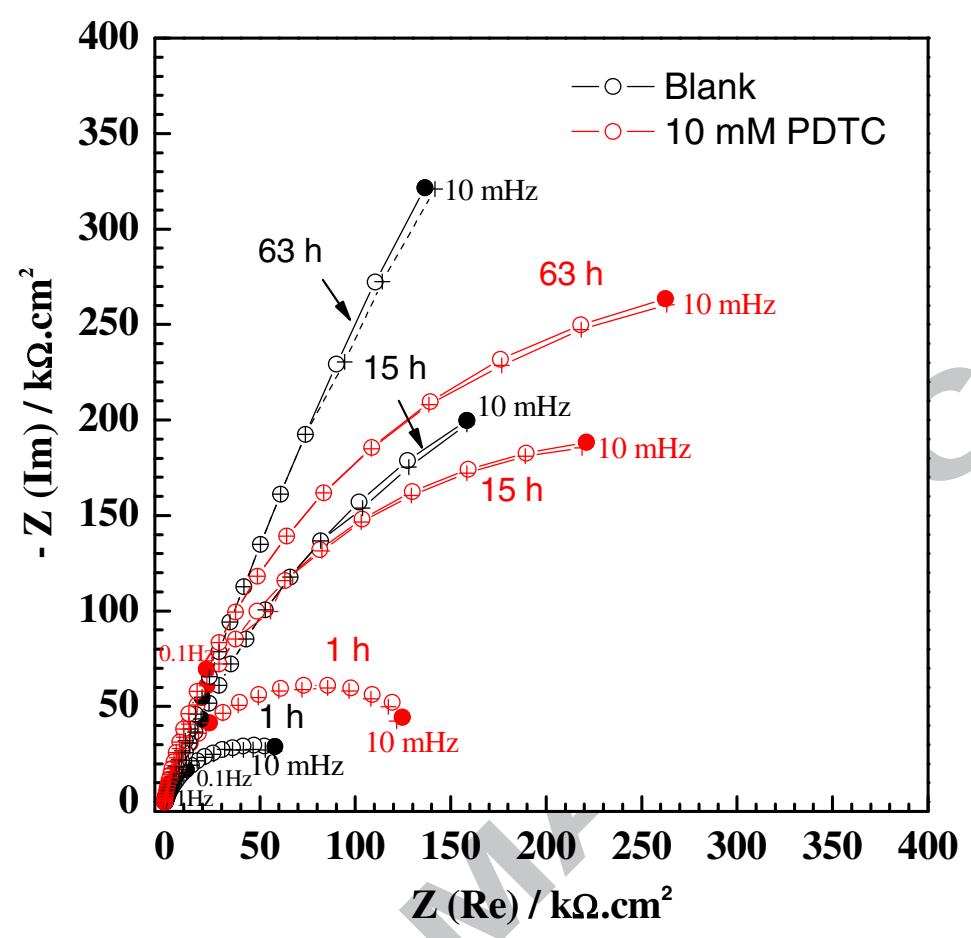

Figure 10: Nyquist plot for pure $\mathrm{Al}$ in $0.2 \mathrm{~g} \mathrm{~L}^{-1} \mathrm{NaCl}$ with or without $10 \mathrm{mM}$ PDTC for different immersion times; stationary electrode at $20^{\circ} \mathrm{C}$. Symbols $=$ experimental data; and line with cross $=$ calculated data. 


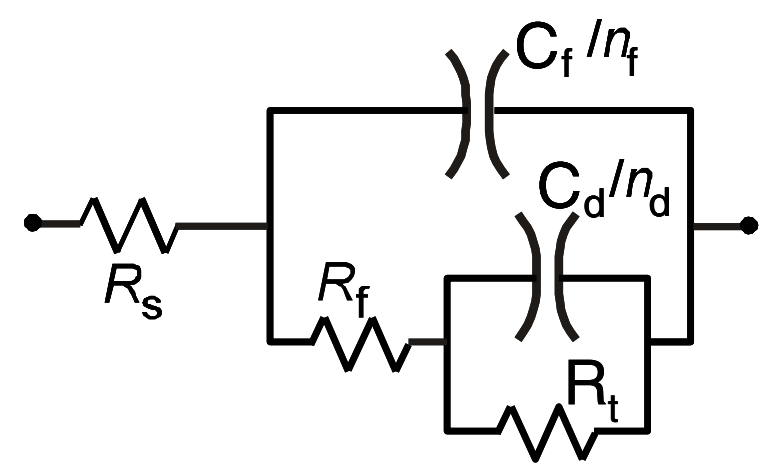

Figure 11: Electrical equivalent circuit to reproduce experimental impedance spectra for pure $\mathrm{Al}$ in $0.2 \mathrm{~g} \mathrm{~L}^{-1}$ $\mathrm{NaCl}$ with or without $10 \mathrm{mM}$ PDTC at $20^{\circ} \mathrm{C}$. 

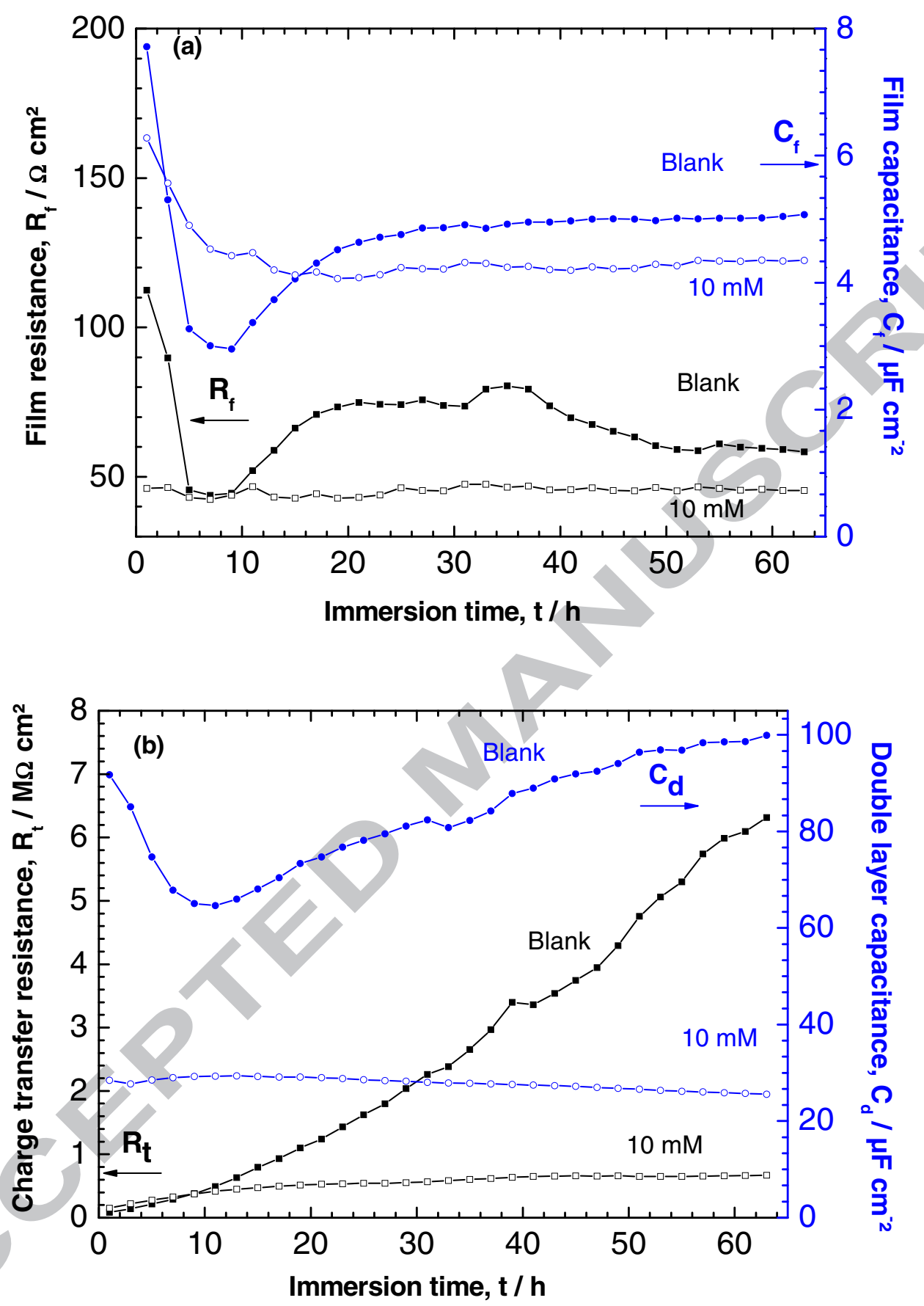

Figure 12: $R_{f}$ and $C_{f}$ (a) (high frequency loop) and $R_{t}$ and $C_{d}$ (b) (low frequency loop) changes as a function of immersion period for pure $\mathrm{Al}$ in $0.2 \mathrm{~g} \mathrm{~L}^{-1} \mathrm{NaCl}$ with or without $10 \mathrm{mM}$ PDTC; stationary electrode at $20^{\circ} \mathrm{C}$. 

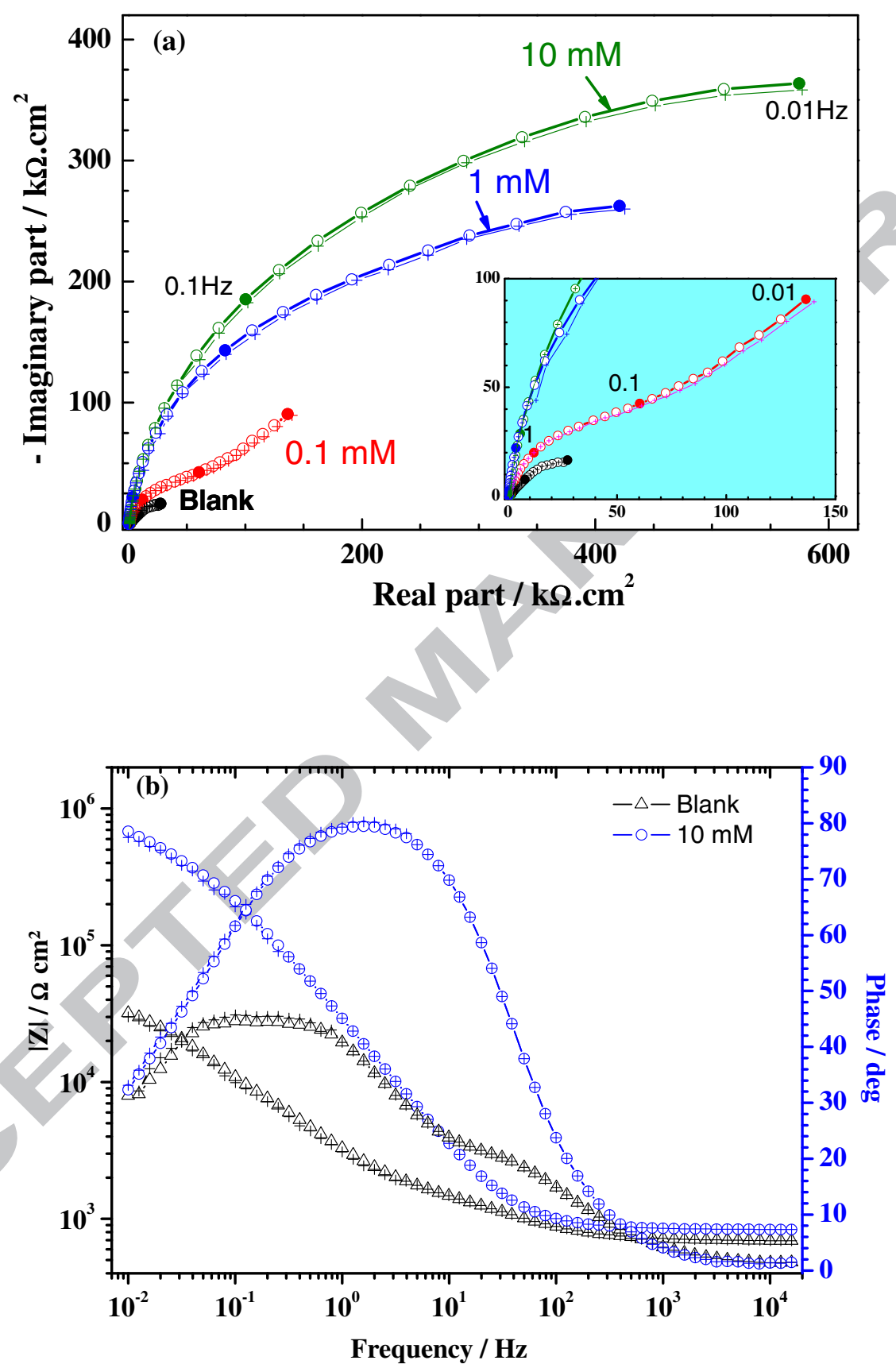

Figure 13: Nyquist (a) and Bode (b) plots for AłA 2024-T3 alloy after 15 hours immersion in $0.2 \mathrm{~g} \mathrm{~L}^{-1} \mathrm{NaCl}$ + PDTC at different concentrations; stationary electrode at $20^{\circ} \mathrm{C}$. The crosses on each diagram correspond to the simulated spectrum. 


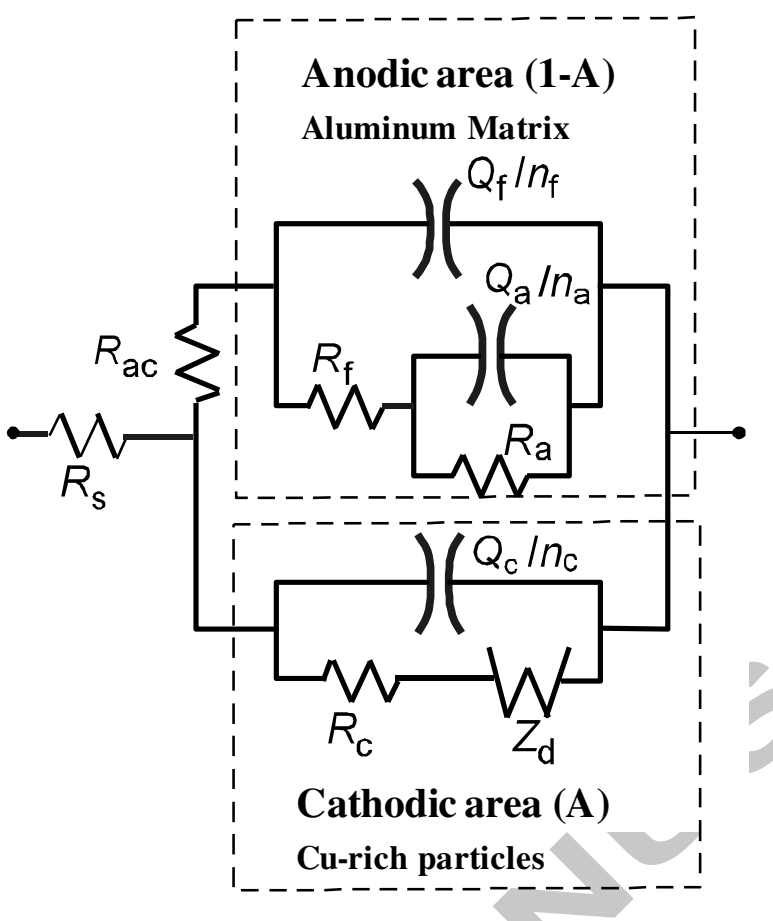

Figure 14: Equivalent electrical circuit describing the galvanic coupling between the impedance of cathodic sites (A, Cu-rich particles) and that of anodic area (1-A, aluminium matrix) and used to model the impedance diagrams on AA 2024-T3 alloy in the presence of PDTC. 


\section{ACCEPTED MANUSCRIPT}

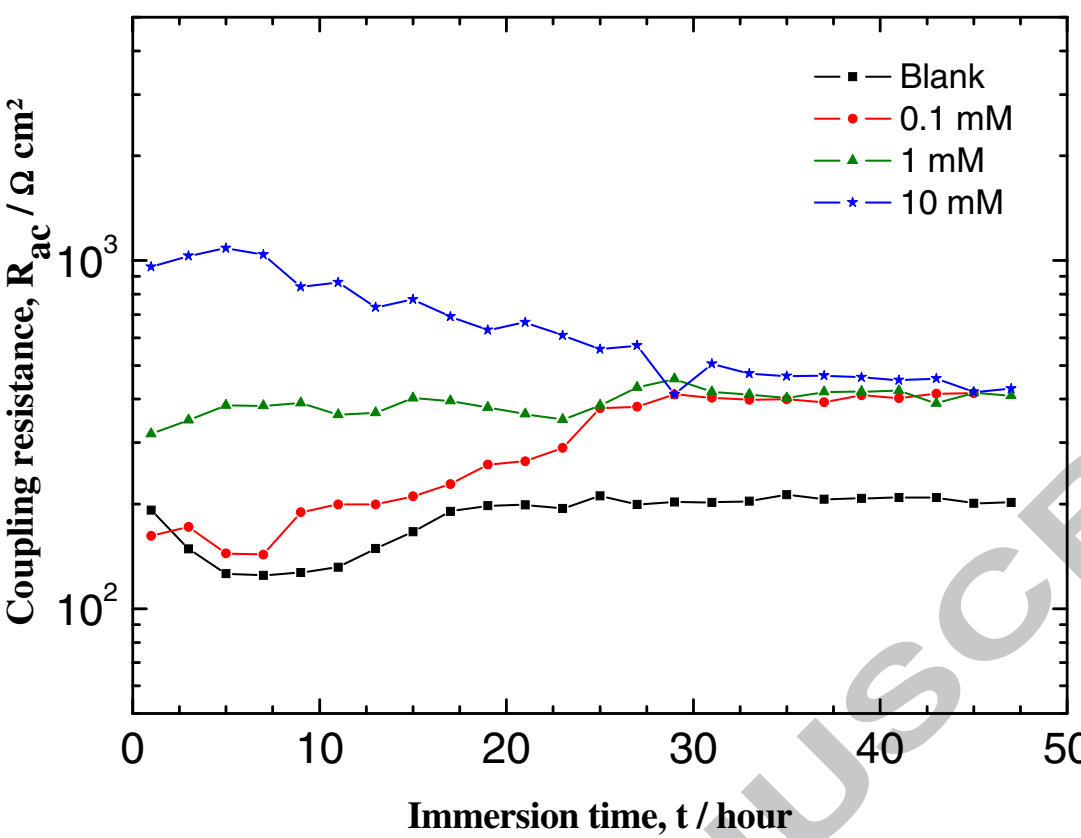

Figure 15: Variation of the galvanic coupling resistance $\mathrm{R}_{\mathrm{ac}}$ with respect to the immersion time. AA 2024-

$\mathrm{T} 3 / 0.2 \mathrm{~g} \mathrm{~L}^{-1}+$ PDTC at different concentrations; stationary electrode at $20^{\circ} \mathrm{C}$. 


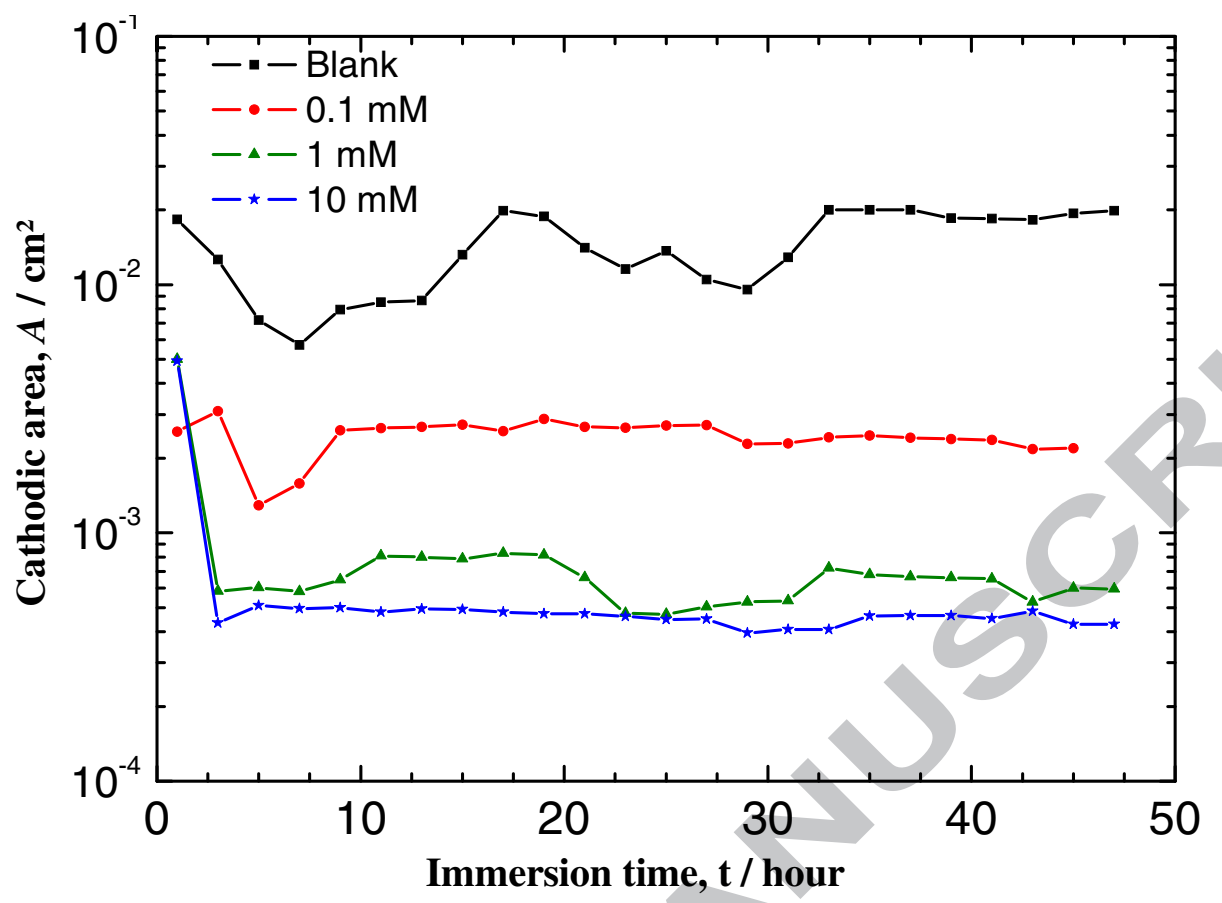

Figure 16: Variation of the cathodic area A with respect to the immersion time.

AA 2024-T3 / $0.2 \mathrm{~g} \mathrm{~L}^{-1}+$ PDTC at different concentrations; stationary electrode at $20^{\circ} \mathrm{C}$. 


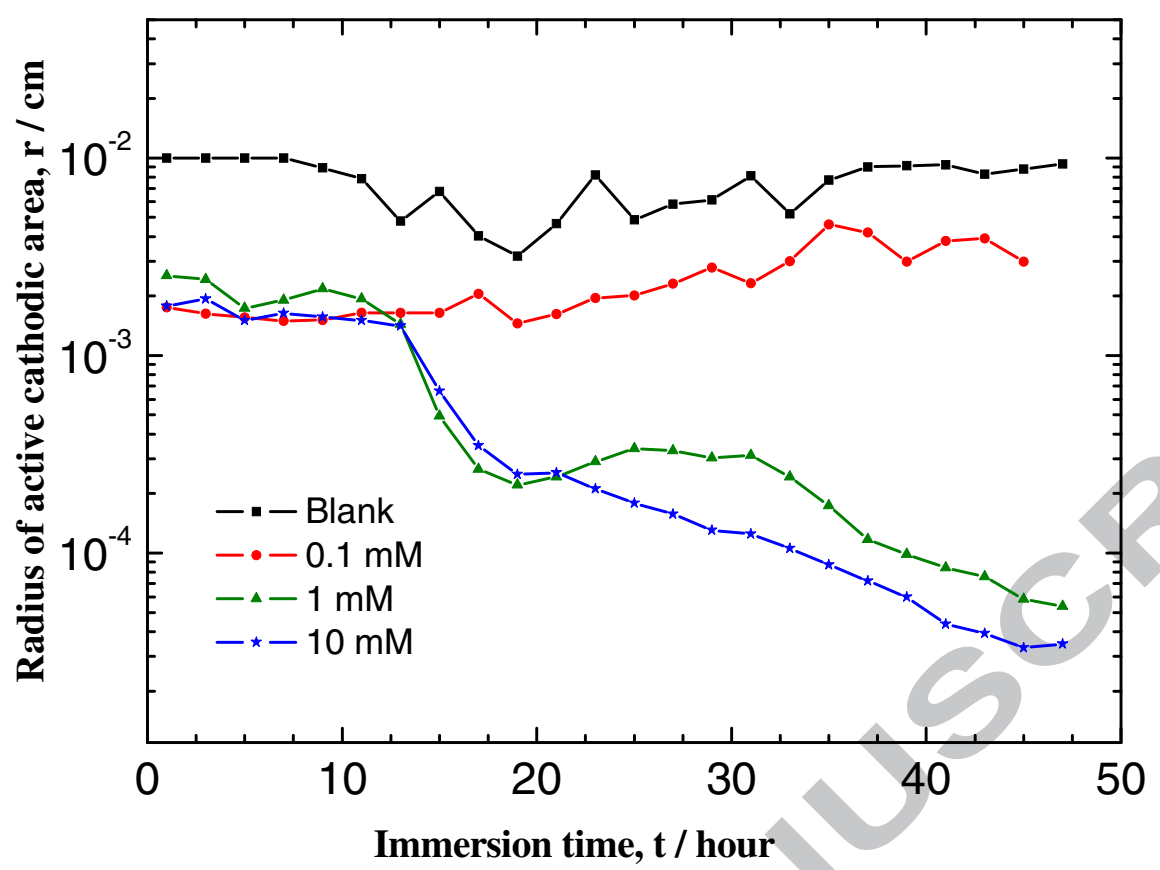

Figure 17: Variation of the radius of the active cathodic area with respect to the immersion time. AA 2024-

$\mathrm{T} 3 / 0.2 \mathrm{~g} \mathrm{~L}^{-1}+$ PDTC at different concentrations; stationary electrode at $20^{\circ} \mathrm{C}$. 


\section{Tables}

Table 1: Composition of AA 2024-T3 alloy.

\begin{tabular}{|c|c|c|c|c|c|c|c|c|c|}
\hline $\mathrm{Al}$ & $\mathrm{Cu}$ & $\mathrm{Mg}$ & $\mathrm{Mn}$ & $\mathrm{Fe}$ & $\mathrm{Zn}$ & $\mathrm{Si}$ & $\mathrm{Cr}$ & $\mathrm{Ga}$ & $\mathrm{Ni}$ \\
\hline $\begin{array}{c}\text { Base } \\
(\mathrm{wt} \%)\end{array}$ & 4.75 & 1.61 & 0.56 & 0.15 & 0.18 & 0.065 & 0.009 & 0.007 & 0.002 \\
\hline
\end{tabular}

Table 2: Composition of the layer vapor deposited on quartz electrodes from AA 2024-T3 alloy target.

\begin{tabular}{|c|c|c|c|c|}
\hline $\mathrm{Al}$ & $\mathrm{Cu}$ & $\mathrm{Mg}$ & $\mathrm{Mn}$ & $\mathrm{Fe}$ \\
\hline Base (wt \%) & 2.79 & 0.29 & 0.52 & 0.35 \\
\hline
\end{tabular}

Table 3: EDX analysis of copper surface after 1 hour immersion in $0.2 \mathrm{~g} \mathrm{~L}^{-1} \mathrm{NaCl}$ $10 \mathrm{mM}$ PDTC at $20^{\circ} \mathrm{C}$.

\begin{tabular}{|c|c|c|c|}
\hline Element & $\mathrm{Cu}$ & $\mathrm{S}$ & $\mathrm{O}$ \\
\hline At\% & 75.53 & 17.55 & 6.93 \\
\hline
\end{tabular}

Table 4: EDX analysis of a Al-Cu-Mg particle after 1 hour immersion in $0.2 \mathrm{~g} \mathrm{~L}^{-1} \mathrm{NaCl}$ $+10 \mathrm{mM}$ PDTC solution at $20^{\circ} \mathrm{C}$.

\begin{tabular}{|c|c|c|c|c|c|}
\hline Element & $\mathrm{Al}$ & $\mathrm{Cu}$ & $\mathrm{Mg}$ & $\mathrm{S}$ & $\mathrm{O}$ \\
\hline $\mathrm{At} \%$ & 56.06 & 17.13 & 12.42 & 10.48 & 3.91 \\
\hline
\end{tabular}




\section{Highlights}

- PDTC interacts with Cu-rich particles.

- PDTC preferentially adsorbs on $\mathrm{Al}-\mathrm{Cu}-\mathrm{Mg}$ particles.

- Oxygen diffusion to cathodic sites is hemispherical.

- PDTC decreases the cathodic sites area leading to a high coupling resistance.

- An electrical circuit containing the galvanic coupling resistance is proposed. 